\title{
Extensional collapse in the Neoproterozoic Araçuaí orogen, eastern Brazil: a setting for reactivation of asymmetric crenulation cleavage
}

\author{
Stephen Marshak ${ }^{\mathrm{a} *}$, Fernando F. Alkmim ${ }^{\mathrm{b}}$, Alan Whittington ${ }^{\mathrm{c}}$, \\ Antônio Carlos Pedrosa-Soares ${ }^{\mathrm{d}}$ \\ ${ }^{a}$ Department of Geology, University of Illinois, Urbana, IL 61801, USA \\ ${ }^{\mathrm{b}}$ Departamento de Geologia, Universidade Federal de Ouro Preto, Ouro Preto, MG 35400, Brazil \\ ${ }^{\mathrm{c}}$ Department of Geology, University of Missouri, Columbia, MO 65211, USA \\ ${ }^{\mathrm{d}}$ CPMTC-Instituto de Geociências, Universidade Federal de Minas Gerais, Belo Horizonte, MG 31279, Brazil
}

Received 16 July 2004; received in revised form 19 July 2005; accepted 21 September 2005

Available online 4 November 2005

\begin{abstract}
The Araçuaí orogen of eastern Brazil is one of many Brasiliano/Pan African orogens formed during the Neoproterozoic assembly of Gondwana. Its western edge, bordering the São Francisco craton, is the Serra do Espinhaço fold-thrust belt, in which top-up-to-the-west (reverse-sense) faults, west-verging folds $\left(\mathrm{F}_{1}\right)$, and east-dipping spaced to phyllitic cleavage $\left(\mathrm{S}_{1}\right)$ developed. We have found that the kinematics of deformation changes markedly at the hinterland margin of this fold-thrust belt. Here, beneath a plateau known as the Chapada Acauã, metadiamictite and fine-grained pelitic schist comprise an east-dipping belt that contains an assemblage of structures indicative of top-down-to-the-east (normal-sense) shear. This assemblage includes a cascade of $F_{2}$ folds that refold $F_{1}$ folds and verge down the dip of the belt's enveloping surfaces, vertical tension gashes, and top-down-to-the-east rotated clasts. Based on the presence of these structures, we propose that the plateau exposes a regional-scale normal-sense shear zone, here called the Chapada Acauã shear zone (CASZ). Because $\mathrm{F}_{2}$ folds refold $F_{1}$ folds, normal-sense shear in the CASZ occurred subsequent to initial west-verging thrusting. Considering this timing of motion in the CASZ, we suggest that the zone accommodated displacement of the internal zone of the Araçuaí orogen down, relative to its foreland fold-thrust belt, and thus played a role in extensional collapse of the orogen. The CASZ trends parallel to preserved thrusts to the west, and thus may represent an inverted thrust fault. Notably, throughout the CASZ, $\mathrm{S}_{1}$ schistosity has been overprinted by a pervasive, west-dipping asymmetric crenulation cleavage $\left(S_{2}\right)$. The sigmoid shape of $S_{1}$ surfaces in $S_{2}$ microlithons require that slip on each $S_{2}$ surface was top-down-to-the-west. $S_{2}$ cleavage is axial-planar to the down-dip verging $F_{2}$ folds. Based on its geometry, we suggest that $S_{2}$ cleavage initiated either as an antithetic extensional crenulation cleavage during reverse-sense shear, or as a near vertical asymmetric crenulation cleavage formed during east-west shortening of a preexisting east-dipping schistosity. Subsequent normal-sense shear in the CASZ reactivated this cleavage, causing clockwise rotation of $S_{2}$ domains (as viewed looking along-strike to the north), in a manner similar to that of rotational 'bookshelf faults'. Such movement could have accommodated concomitant vertical flattening of the CASZ during extensional collapse.
\end{abstract}

(C) 2005 Elsevier Ltd. All rights reserved.

Keywords: Araçuaí orogen; Crenulation cleavage; Brasiliano orogeny; Orogenic collapse; Shear zone; Crustal extension; Neoproterozoic; Extensional crenulation cleavage; Espinhaço fold-thrust belt; Macaúbas basin

\section{Introduction}

When continental crust thickens during convergent or collisional orogeny, gravitational loading may trigger

\footnotetext{
* Corresponding author.

E-mail address: smarshak@uiuc.edu (S. Marshak).
}

0191-8141/\$ - see front matter () 2005 Elsevier Ltd. All rights reserved. doi:10.1016/j.jsg.2005.09.006 extensional collapse (or 'orogenic collapse') above a normal-sense shear zone (or 'extensional detachment'). Extensional collapse has been linked to the rise of posttectonic granites and to the growth of late- to post-tectonic sedimentary basins in the interior of orogens (Dewey, 1977; Burchfiel and Royden, 1985; Norton, 1986; Ménard and Molnar, 1988; Platt and Vissers, 1989; Malavieille et al., 1990; Malavieille and Taboada, 1991; Burchfiel et al., 1992; Malavieille, 1993; Rey et al., 2001). Work by PedrosaSoares et al. (2001), among others, demonstrates that the 
interior of the Neoproterozoic-age Araçuaí orogen of eastern Brazil contains both late- to post-tectonic granites as well as post-tectonic sedimentary accumulations. The presence of these features hints that the orogen endured a phase of extensional collapse. To test this concept, we carried out structural analysis across the foreland/hinterland boundary of the Araçuaí orogen, with the goal of determining whether the region contains a structural record of extensional deformation. Our results point to the existence of a previously unrecognized regional-scale normal-sense shear zone, here called the Chapada Acauã shear zone (CASZ), which developed along the hinterland edge of the orogen's fold-thrust belt. This shear zone dips east, parallel to faults in the fold-thrust belt to the west.

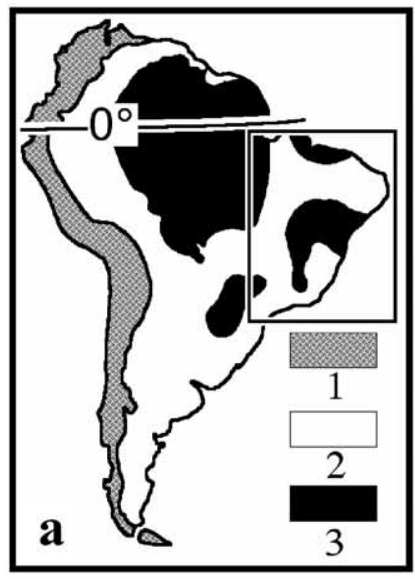

Phanerozoic cover

Brasiliano orogens; structural trends shown
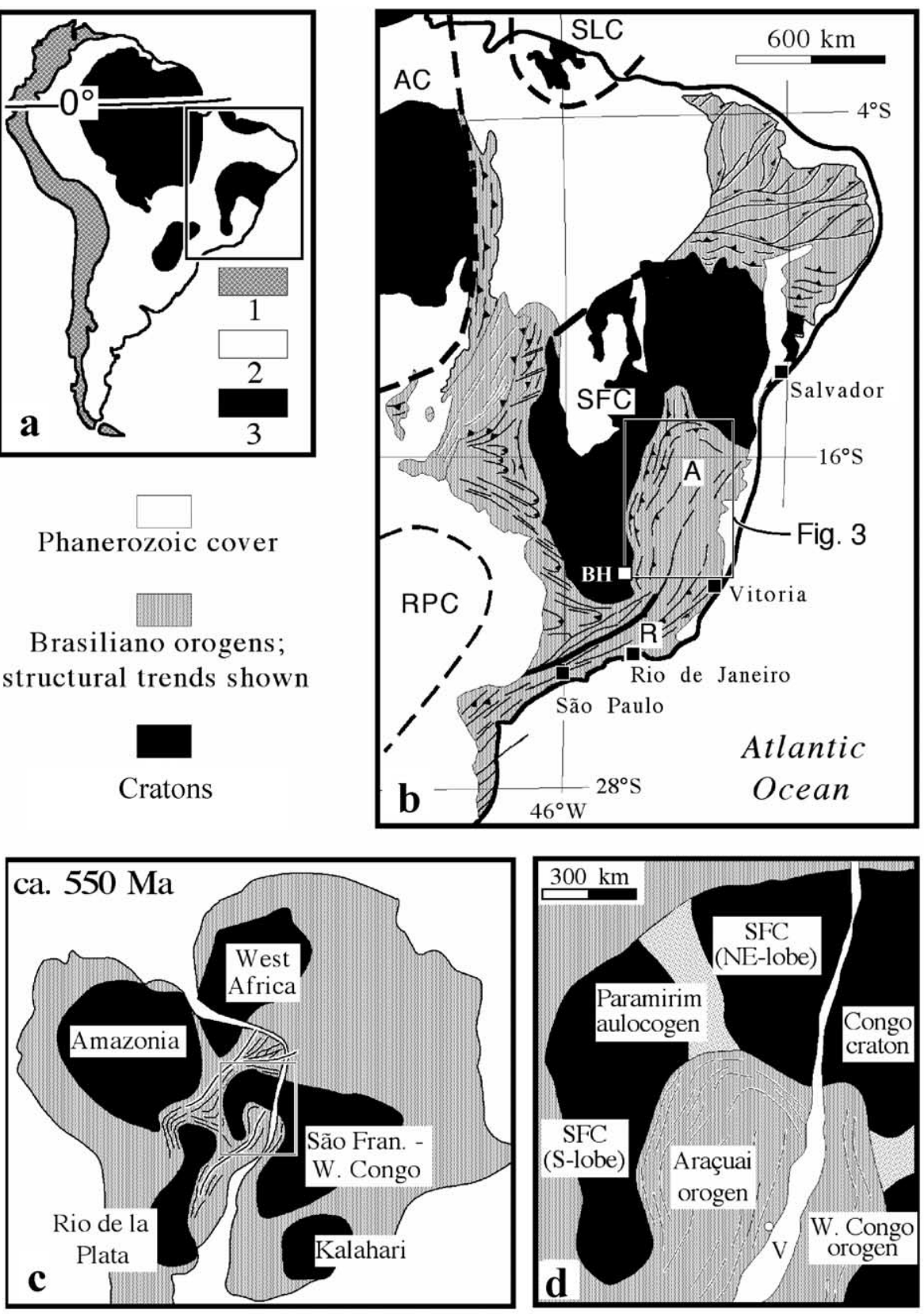

Fig. 1. (a) A location map of South America, showing the distribution of cratons and younger tectonic elements. On this map: $1=$ regions involved in the Andean orogeny; 2 = regions underlain by Brasiliano (Neoproterozoic) or younger (Paleozoic) orogenic belts; $3=$ regions underlain by cratons, meaning relatively stable crustal blocks that were not affected by the Brasiliano or younger orogenies. (b) A regional map of eastern Brazil. The heavy dashed lines outline the cratons, and white areas represent Phanerozoic cover. SFC $=$ São Francisco craton, $\mathrm{AC}=\mathrm{Amazon}$ craton, $\mathrm{RPC}=\mathrm{Rio}$ de la $\mathrm{Plata}$ craton; $\mathrm{SLC}=\mathrm{São}$ Luis craton; $A=$ Araçuaí Orogen; $\mathrm{R}=$ Ribeira Belt. Note that the Araçuaí Orogen consists of rocks in the region between the coast and the São Francisco craton, north of the latitude of Vitória. (c) Reconstruction of South America and Africa in West Gondwana, prior to opening of the South Atlantic Ocean, showing the connection between the São Francisco craton and the Congo craton. (d) Close-up of the boxed region in 'c' showing how the Araçuaí-West Congo Orogen fills the tongue-shaped enclave between the São Francisco and Congo cratons. V=Vitória. 
Considering its position and its kinematics, we suggest that the CASZ represents an inverted thrust, and that it served as a detachment accommodating extensional collapse of the Araçuaí orogen's internal zone relative to its foreland foldthrust belt. Significantly, exposures of the CASZ do not contain mylonite, in contrast with other examples of regional extensional detachments. Rather, schist in the CASZ displays a pervasive asymmetric crenulation cleavage. This cleavage dips west, and thus is antithetic to the enveloping surfaces of the CASZ.

The purpose of this paper is two-fold. First, we present evidence for the existence of the CASZ and for the kinematics of displacement across it. Then, we describe the crenulation cleavage within the shear zone and discuss a model for the evolution this cleavage. We suggest that the cleavage initiated during thrusting, and was reactivated during normal-sense displacement of the CASZ. To set the stage for our discussion of the CASZ, and the crenulation cleavage that it contains, we begin by outlining the geologic setting of the Araçuaí orogen.

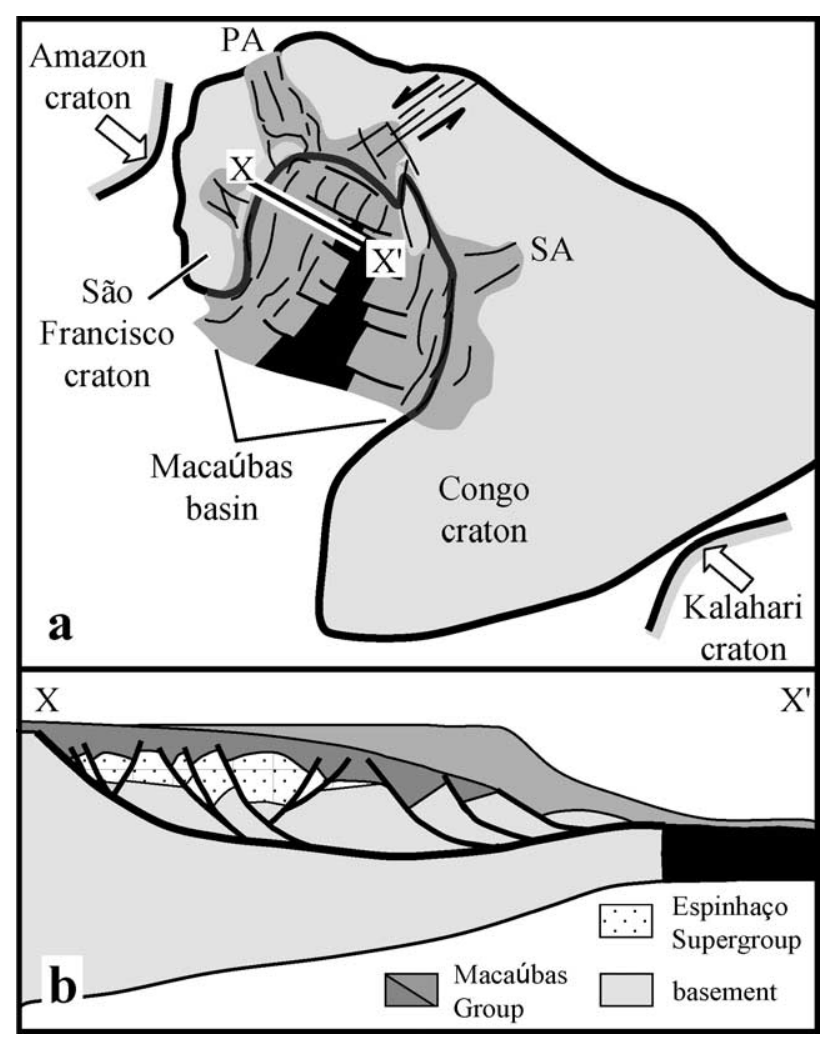

Fig. 2. (a) This model portrays the Macaúbas basin at around $800 \mathrm{Ma}$ as a Red Sea-type ocean formed between the São Francisco and Congo arms of the continent. This ocean tapered northwards into two aulocogens. PA= Paramirim aulacogen; SA=Sangha aulacogen. (b) A simplified crosssection of the eastern margin of the São Francisco craton at about $800 \mathrm{Ma}$, showing an interpretation of the Macaúbas Group depositional setting. The unit buries the Espinhaço Supergroup rift fill, and grades from proximal facies (darker pattern) on the west to distal facies (lighter pattern) on the east. The line of section is shown on the map of ' $a$ '.

\section{Geologic setting}

The continental crust of Brazil consists of four major cratons (relatively stable blocks of Archean and Paleoproterozoic crust) stitched together by Neoproterozoic-age Brasiliano (= Pan African) orogens. One of these cratons, the São Francisco craton, underlies part of eastern Brazil. This craton's map-view shape resembles the profile of a horse's head (Fig. 1). According to tectonic reconstructions of West Gondwana (Dalziel, 1997), the northeast arm of the São Francisco craton connected to the Congo craton of Africa, prior to opening of the South Atlantic Ocean. This combination, a single coherent crustal block called the São Francisco-Congo craton, lay in the center of West Gondwana and had the shape of a lopsided, upside-down 'U'. A Neoproterozoic orogen, called the Araçuaí-West Congo orogen, developed in the tongue-shaped enclave that occupied the interior of the upside-down ' $U$ ' (Fig. 1d; Porada, 1989; Brito-Neves and Cordani, 1991; PedrosaSoares et al., 1992, 1998, 2001; Trompette, 1997; Uhlein et al., 1998; Cunningham et al., 1998; Brito-Neves et al., 1999; Alkmim et al., 2001; Martins-Neto et al., 2001; Tack et al., 2001). When the South Atlantic Ocean opened in the Mesozoic, the Araçuaí-West Congo orogen split in two, along its length, stranding the Araçuaí orogen and the São Francisco craton in Brazil, while the West Congo orogen and the Congo craton remained in Africa. In this context, the Araçuaí orogen is defined as the Neoproterozoic orogenic domain that lies between the eastern edge of the São Francisco craton and east coast of Brazil, between latitudes $15^{\circ} \mathrm{S}$ and $21^{\circ} \mathrm{S}$ (Pedrosa-Soares et al., 2001).

Current tectonic models (Pedrosa-Soares et al., 1992, 1998, 2001; Uhlein et al., 1998) suggest that the Araçuaí orogen developed in response to closure of a composite sedimentary basin. Basin formation began at about $1.75 \mathrm{Ga}$, with the development of the unsuccessful Espinhaço rift (named for the stratigraphic unit, the Espinhaço Supergroup, which filled it). Remnants of the Espinhaço rift can be traced northwards along the eastern edge of the São Francisco craton into a trough, called the Paramirim aulacogen, that defines the border between the northeast and southern lobes of the craton (Fig. 1d). A second rifting event, commencing at about $0.95 \mathrm{Ga}$, generated a broader basin that is superimposed on, and extends eastwards from, the Espinhaço rift (Pedrosa-Soares et al., 1992, 1998, 2001; Uhlein et al., 1998). This second basin is named the Macaúbas basin, after the stratigraphic unit (the Macaúbas Group) that filled it (Fig. 2a and b). To the south of latitude $17^{\circ} \mathrm{S}$, the Macaúbas basin opened sufficiently to produce oceanic crust, but to the north of this latitude, the basin was ensialic (Pedrosa-Soares et al., 1998, 2001). In other words, the Macaúbas basin tapered from a narrow ocean basin to the south into an ensialic rift to the north. In this regard, it resembled the present-day Red Sea, which tapers to the north into the Gulf of Suez. Thus, the Macaúbas Group 
represents a passive-margin basin fill roughly to the south of $17^{\circ} 30^{\prime} \mathrm{S}$, and an ensialic basin fill to the north.

Available radiometric dates indicate that formation of the Araçuaí orogen by closure of the Macaúbas and Espinhaço basins took place at the end of the Neoproterozoic (ca. 625$560 \mathrm{Ma}$; Pedrosa-Soares et al., 2001). Development of this orogen involved subduction of the oceanic parts of the Macaúbas basin, and inversion of its ensialic domains. Relicts of the Espinhaço rift bordering the Macaúbas basin were also inverted at this time (Marshak and Alkmim, 1989; Dussin and Dussin, 1995; Uhlein et al., 1998). Closure produced a fold-thrust belt, the Espinhaço fold-thrust belt, along the eastern edge of the São Francisco craton, and a magmatic province called the Mucuri granite province, in the interior of the orogen. Plutons of the Mucuri province intruded strata of the Macaúbas basin during pre-, syn-, and post-collisional stages. Campos Neto (2000) and Alkmim et al. (2001) suggest that the compressional stress driving crustal shortening during development of the Araçuaí orogen resulted from collision of the Amazon craton with the western margin of the São Francisco craton and collision of the Kalahari craton with the eastern margin of the Congo craton (Fig. 2a).

The specific study area that we discuss in this paper comprises the western portion of the Araçuaí orogen, specifically the region between the eastern edge of the São Francisco craton and the western edge of the Mucuri granite province (Figs. 3 and 4a). For purposes of discussion, we group the various rock units involved in the Araçuaí orogen into five tectonostratigraphic assemblages (Table 1), combinations of which comprise three tectonic domains (named, from west to east: the Serra do Espinhaço domain, the Chapada Acauã domain, and the Turmalina domain; Fig. 4b).

The Serra do Espinhaço domain comprises the broad Serra do Espinhaço fold-thrust belt, and is manifested topographically by a $60-\mathrm{km}$-wide terrain of ridges that reach elevations of $2000 \mathrm{~m}$. In this domain, strata of the Espinhaço Supergroup and the Macaúbas Group, as well as slices of Archean basement, moved westward on east-dipping thrusts up onto the edge of the São Francisco craton (Uhlein et al., 1986, 1998; Almeida-Abreu and Pflug, 1994; Dussin and

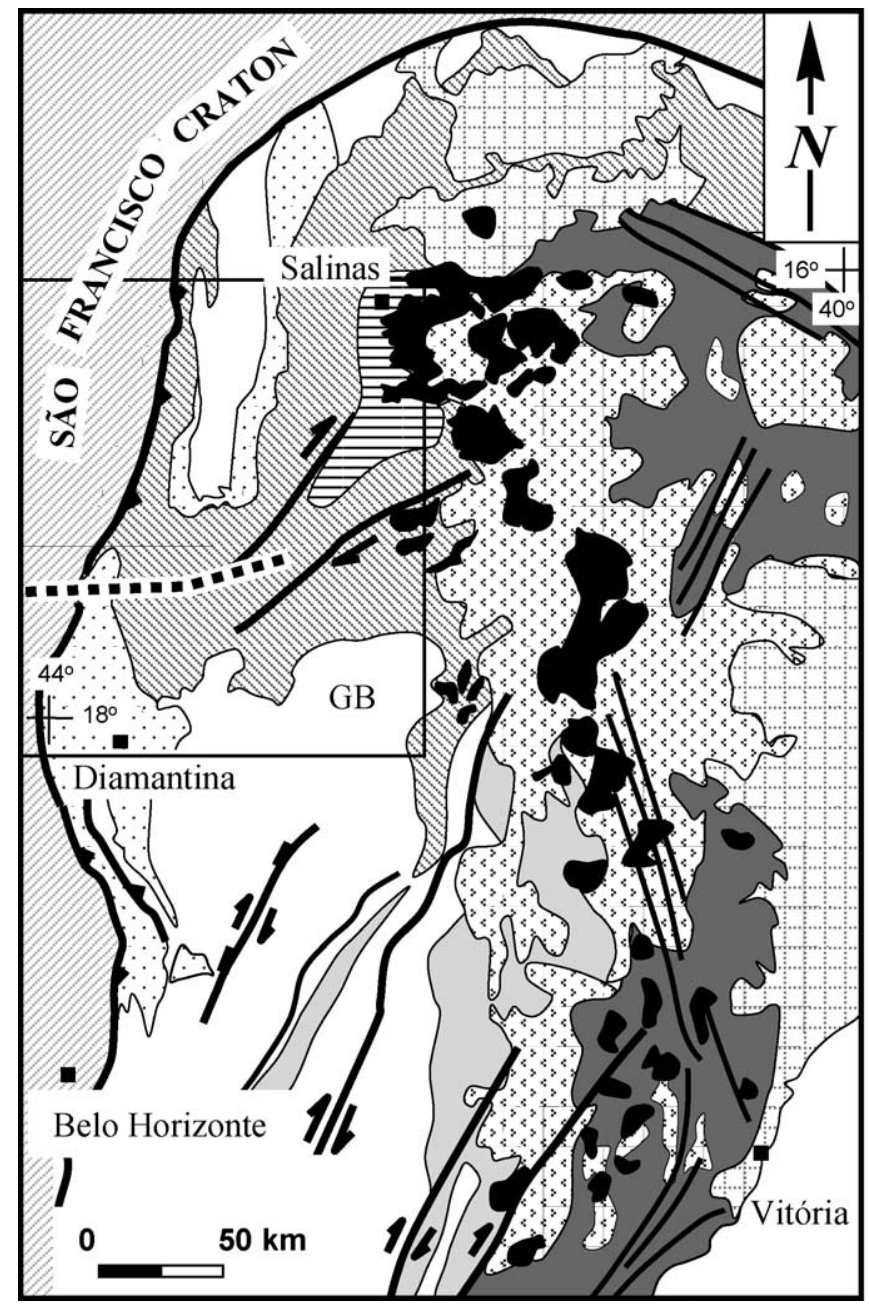

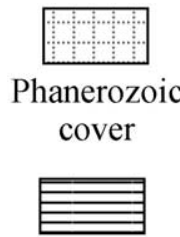

Salinas Formation
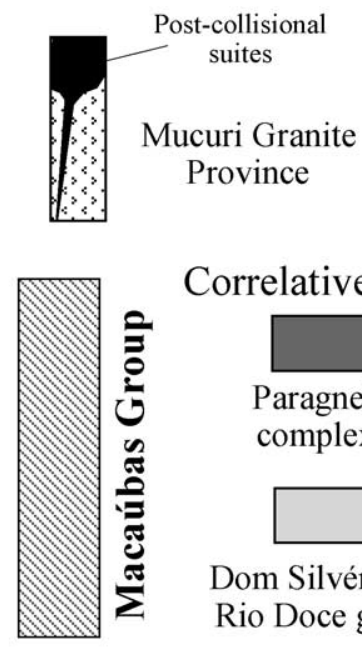

\section{Correlative units}

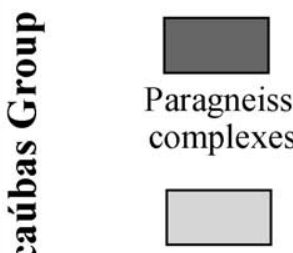

Dom Silvério and Rio Doce groups

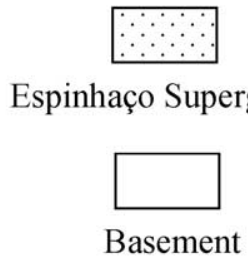

Fig. 3. Simplified map of the Araçuaí orogen (modified from Pedrosa-Soares et al., 2001); location shown on Fig. 1b, the box delineates our study area, and the heavy dashed lines indicates the location of the transect portrayed by Fig. 7. GB= Guanhães basement block. 
(a)

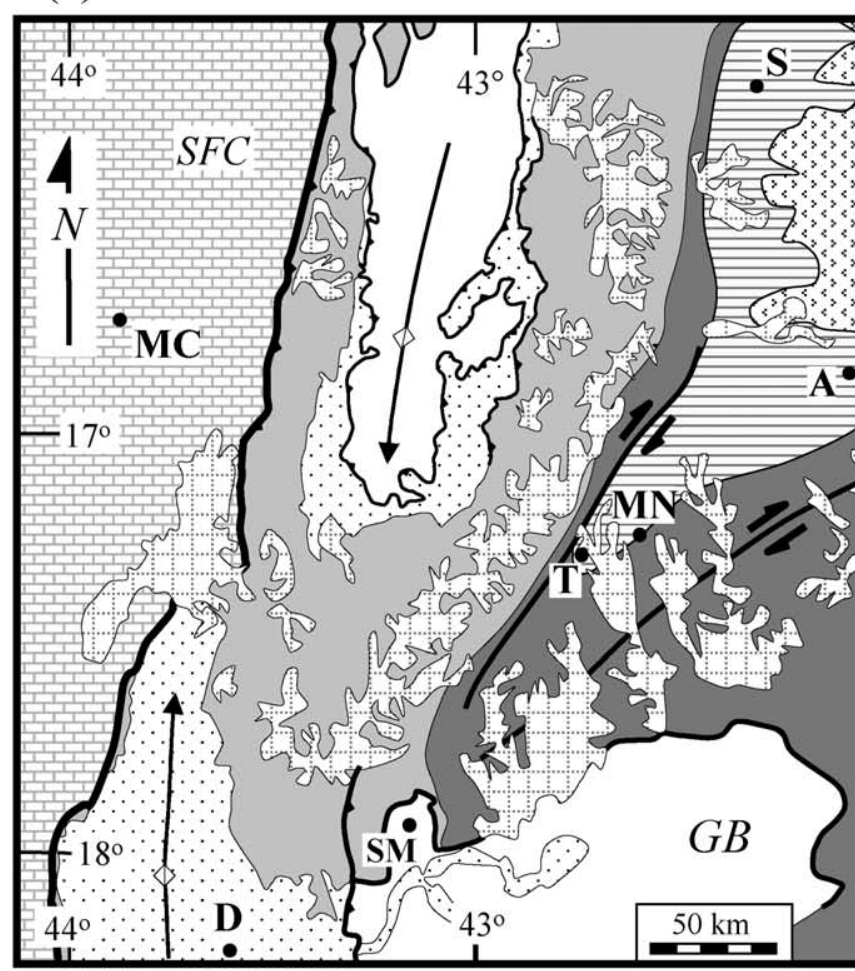

1 Cenozoic cover units

Neoprotero./Cambrian granites

Ealinas Formation

craton cover units

Macaúbas Gp. proximal facies

Espinhaço Sgp

basement (b)

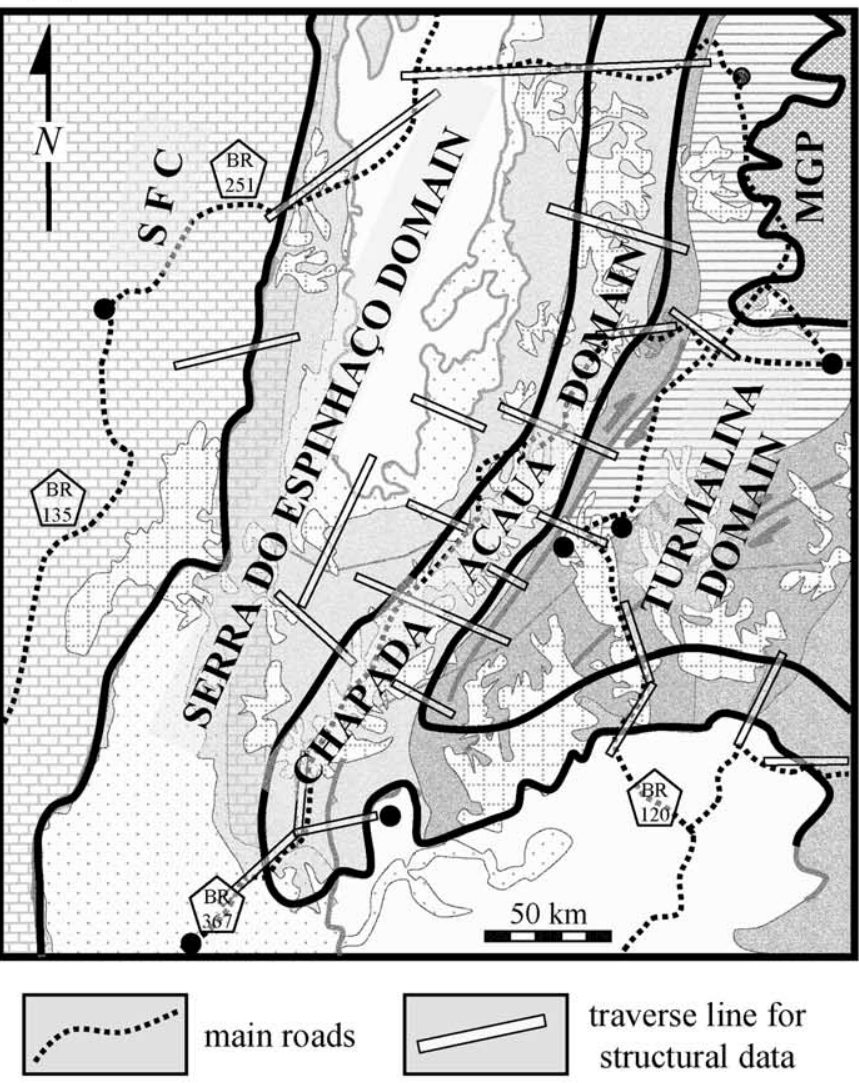

Fig. 4. (a) A simplified geologic map of our study area, delineating exposures of major stratigraphic units. The heavy black line indicates the eastern edge of the São Francisco craton. Cities: MC $=$ Montes Claros; $\mathrm{D}=$ Diamantina; $\mathrm{SM}=$ Senador Modestino; $\mathrm{T}=$ Turmalina; $\mathrm{MN}=$ Minas Novas; $\mathrm{A}=$ Araçuaí; $\mathrm{S}=$ Salinas. $\mathrm{GB}=$ Guanhães basement block. (b) Distribution of the three structural domains (Serra do Espinhaço, Chapada Acauã, Turmalina), as defined in the text. Part (a) serves as the base for this map. Note that the eastern edge of the Turmalina domain is the western intrusive contact of post-collisional plutons of the Mucuri granite province (MGP). The traverse lines shown on the map indicate the locations at which we collected structural data. 
Table 1

Principal tectonostratigraphic units of the Araçuaí orogen

Mucuri granite province. This is a north-south-trending belt of granitic rocks that bisects the Araçuaí orogen. This province, which is over $350 \mathrm{~km}$ long and $100 \mathrm{~km}$ wide, includes numerous distinct Neoproterozoic and Cambrian plutons formed during at least five phases of intrusion between 625 and $490 \mathrm{Ma}$ (Pedrosa-Soares and Wiedeman-Leonardos, 2000). Later phases are post-collisional intrusions, free of the regional ductile foliation.

Salinas Formation. This unit consists of graywacke, pelite, and conglomerate, deposited as deep-water turbidites between 568 and $500 \mathrm{Ma}$, and metamorphosed to greenschist facies conditions (Lima et al., 2002). These sediments, derived from the magmatic arc of the orogen, occur in intramontane basins formed subsequently to deformation that affects underlying units but prior to the last phase(s) of intrusion.

Macaúbas Group and correlative units. These strata were deposited over and to the east of deposits of the Espinhaço Supergroup, during and subsequent to rifting that began about $0.95-0.88 \mathrm{Ga}$. The basal (rift-stage) units of the Macaúbas Group, exposed on the eastern side of the Macaúbas basin, include strata deposited during a Neoproterozoic glacial episode, and are now represented by outcrops of metadiamictite, quartzite and pelitic schist (Uhlein et al., 1999; Martins-Neto et al., 2001). These strata grade eastwards into upper (passive-margin stage) units that include both deepmarine turbidites now represented by outcrops of pelitic schist and metasandstone, and slivers of an ocean-floor assemblage now represented by outcrops of mica schist, metachert, banded iron formation, and orthoamphibolites. The ocean-floor assemblage comprises the Ribeirão da Folha Formation (Pedrosa-Soares et al., 2001; Lima et al., 2002). Highergrade correlatives to the Macaúbas Group include the Dom Silvério Group (biotite-garnet schist, quartzite, mafic and locally ultramafic rocks, banded iron formation, and manganese-rich rocks, also representing a deep-ocean sedimentary assemblage) and the Rio Doce Group (amphibolite-facies pelitic schist and banded gneisses), both of which crop out to the south of our study area. The Macaúbas Group may also correlate with protoliths of high-grade paragneiss complexes that lie to the north and east of the Mucuri granite province.

Espinhaço Supergroup. These strata were deposited in a rift basin that formed along the eastern margin of the São Francisco craton beginning at ca. 1.75 Ga (Dussin and Dussin, 1995; Uhlein et al., 1998). They were metamorphosed to low grade during the Brasiliano Orogeny, and now consist of quartzite, meta-conglomerate, and phyllite. Intercalations of bimodal meta-volcanic rocks occur in basal units of the Supergroup.

Basement. This unit consists of all rocks of the study area that are older than 1.8 Ga. In the Araçuaí orogen, basement includes Archean and Paleoproterozoic metamorphic complexes and intrusives, as well as pre-1. 8 Ga supracrustal sequences.
Dussin, 1995). The western topographic front of the range partially coincides with a major emergent ramp. To the west of this ramp, on the foreland side of our study area, a thinskinned detachment propagated westward, beneath platform strata of the São Francisco craton (Marshak and Alkmim, 1989).

The Chapada Acauã domain, which is the principal focus of this paper, is a $15-45-\mathrm{km}$-wide plateau ('chapada' is the Portuguese word for a relatively high plain), whose surface lies at an average elevation of $1000 \mathrm{~m}$. This plateau has been dissected by river valleys, some of which cut down to elevations of as low as $500 \mathrm{~m}$. The Chapada Acauã domain contains an ESE-dipping package of Macaúbas pelitic schist, metadiamictite and quartzite.

The Turmalina domain encompasses the valley of the Araçuaí River. Here, bedrock consists of exposures of the Macaúbas Group and Salinas Formation. Strata of the Salinas Formation are notably lower in metamorphic grade than those of the Chapada Acauã domain to the west, and do not display the structural assemblage found in the older Macaúbas Group. At its eastern edge, rocks of the Turmalina domain are cut by intrusives of the Mucuri granite province. The intrusives have been eroded to form a landscape of spectacular sugarloaf mountains. Plutons in the Mucuri granite province a range in age from about 625 to 490 Ma. Pedrosa-Soares and Wiedemann-Leonardos (2000) recognize five phases of intrusion. Earlier phases, which are calk-alkaline and related to a magmatic arc formed on an active continental margin, occur only south of latitude $17^{\circ} 30^{\prime} \mathrm{S}$. The termination of arc and the occurrence of Neoproterozoic oceanic slivers at this latitude led Pedrosa-Soares at al. (2001) to consider $17^{\circ} 30^{\prime} \mathrm{S}$ to be the northern limit of ocean floor beneath the Macaúbas Basin. Some of the later phases of intrusion in the Mucuri granite province appear to be a consequence of decompression melting (Pedrosa-Soares and Wiedemann-Leonardos, 2000). Macaúbas Group correlative units reach amphibolite facies adjacent to and within the Mucuri granite province.

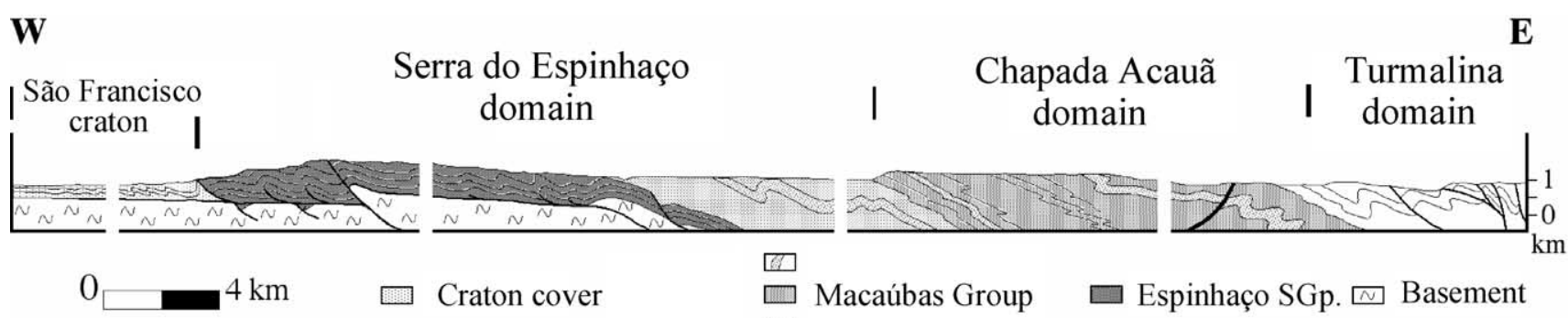

Fig. 5. This composite structure section across the western Araçuaí orogen shows three structural domains. The approximate location of this section is shown on Fig. 1. Note that a portion of each domain has been removed (blank lines), to allow the section to fit on a page; the true length of the section is about $40 \%$ longer than shown. 


\section{Observations}

In order to understand the kinematics of deformation in the western Araçuaí orogen, we undertook detailed structural analysis at about 250 stations distributed across the portion of the Serra do Espinhaço, Chapada Acauã, and Turmalina domains that lies between latitudes $16^{\circ} \mathrm{S}$ and $18^{\circ} \mathrm{S}$. This study area, therefore, traverses the orogen from the western front of the Serra do Espinhaço to the western edge of the Mucuri granite province. Our measurement stations concentrate along transect lines that follow access routes provided by roads and stream valleys (Fig. 4b). We combine our results in a single composite structure section,
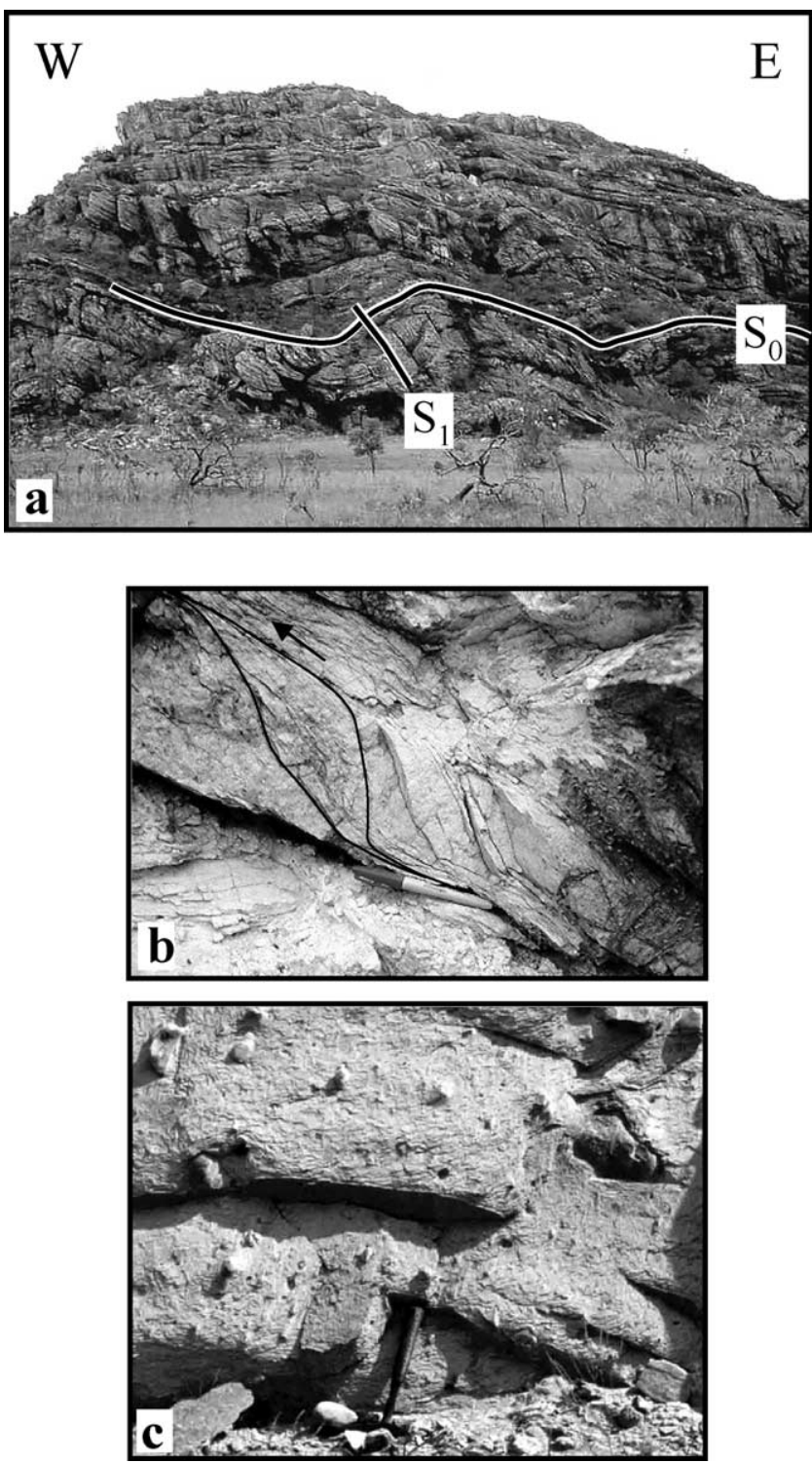

Fig. 6. (a) Photo of west-verging folds in the Serra do Espinhaço fold-thrust belt. This structure involves quartzite containing spaced cleavage. The outcrop face is about $100 \mathrm{~m}$ from side to side. (b) Photo showing foliation sigmoids of a thrust shear zone in the Serra do Espinhaço domain. (c) Photo of stretched clasts of a Macaúbas metadiamictite in the Serra do Espinhaço domain. The attitude of the stretching lineation is 095/40. representative of an east-west cross-section roughly at latitude $17^{\circ} 20^{\prime} \mathrm{S}$ (Fig. 5). In the following description, we characterize each structural domain separately, in order from west to east. For each domain, we describe the structural assemblages that it contains and infer the kinematic significance of this assemblage. We will discuss the assemblage of the Chapada Acauã in the most detail.

\subsection{Structures of the Serra do Espinhaço domain}

The Serra do Espinhaço domain is the internal portion of a west-verging fold-thrust belt (Uhlein et al., 1986, 1998; Almeida-Abreu and Pflug, 1994; Dussin and Dussin, 1995). Thus, this domain contains west-verging folds, east-dipping thrust ramps, detachment faults, and local duplexes containing east-dipping ramps (Fig. 6a and b). Fault surfaces are defined by mylonites in which $\mathrm{C}-\mathrm{S}$ fabrics and porphyroclast tails indicate top-up-to-the-west movement. Slip lineations, defined by streaks of microscopic mica flakes, quartz fibers, and stretched grains, plunge east, down the dip of foliation. Most outcrops within the Serra do Espinhaço domain expose thick-bedded fluvial and eolian quartzites, interbedded with pelitic horizons (Uhlein et al., 1986; Dussin and Dussin, 1995; Grossi-Sad et al., 1997). The quartzites acted as mechanical struts that buckled into large open to tight west-verging inclined folds $\left(\mathrm{F}_{1}\right)$ containing a steep axial-planar cleavage $\left(S_{1}\right)$ that dips east (Fig. 6a). Thin-bedded pelitic intervals locally buckled to form tight mesoscopic west-verging folds containing an east-dipping axial-planar phyllitic cleavage.

At the east-dipping unconformity between older Espinhaço quartzites and younger Macaúbas metadiamictites, near the eastern margin of the domain, metadiamictites contain an east-dipping phyllitic schistosity $\left(\mathrm{S}_{1}\right)$ that intersects relict bedding $\left(\mathrm{S}_{0}\right)$ at an acute angle $-\mathrm{S}_{0}$ at this contact dips slightly less steeply than does $\mathrm{S}_{1}$. A down-dip mineral lineation, defined by stretched quartz grains and by mica streaks, decorates the surface of foliation planes in the contact zone. Softer pebbles within Macaúbas metadiamictite layers have been stretched in the plane of shear to an aspect ratio of about 5:1 (Fig. 6c), with their long axis parallel to the mineral lineation. In shear zones, pressureshadow tails on these clasts indicate top-up-to-the west sense of slip. Quartzite layers that occur within the metadiamictites above the contact have buckled into folds that verge up-dip (i.e. west). The limbs of these folds have been stretched and boudined. Taken together, structures along the Espinhaço/Macaúbas contact indicates that this unconformity was employed as a thrust-sense shear zone during the Brasiliano orogeny.

\subsection{Structures of the Chapada Acauã domain}

The central portion of our study area is an approximately 15-45-km-wide plateau, here called the Chapada Acauã domain (Figs. 4b and 5). Bedrock of the Chapada Acauã 
domain consists of metamorphosed pelite, metadiamictite, quartzite and subordinate volcanics of the Macaúbas Group. These rocks occur in an overall east-dipping belt, meaning that the domain is bounded on the top and bottom by enveloping surfaces that dip, on average, $35^{\circ}$ east. Metamorphic grade increases progressively from lowergreenschist in the west (manifested by occurrence of phyllitic metadiamictite and phyllite), to high greenschist in the east (manifested by occurrence of fine-grained garnetmica schist). The appearance of staurolite in garnet-mica schist in the eastern border of the domain records the transition to the lower amphibolite facies.

Within the Chapada Acauã domain, rocks retain an $S_{1}$ schistosity that is axial-planar to west-verging (top-up-tothe-west) $F_{1}$ folds (Fig. 7a-d). But the $S_{1}$ of the Chapada Acauã domain, in contrast to that of the Serra do Espinhaço domain, has been transposed almost into parallelism with $\mathrm{S}_{0}$ everywhere except in the relict hinges of $F_{1}$ folds and in quartzite beds. $\mathrm{F}_{1}$ folds of the Chapada Acauã domain are, in general, tight to isoclinal, and thus differ in character from those of the Serra do Espinhaço domain. Overall, $S_{1}$
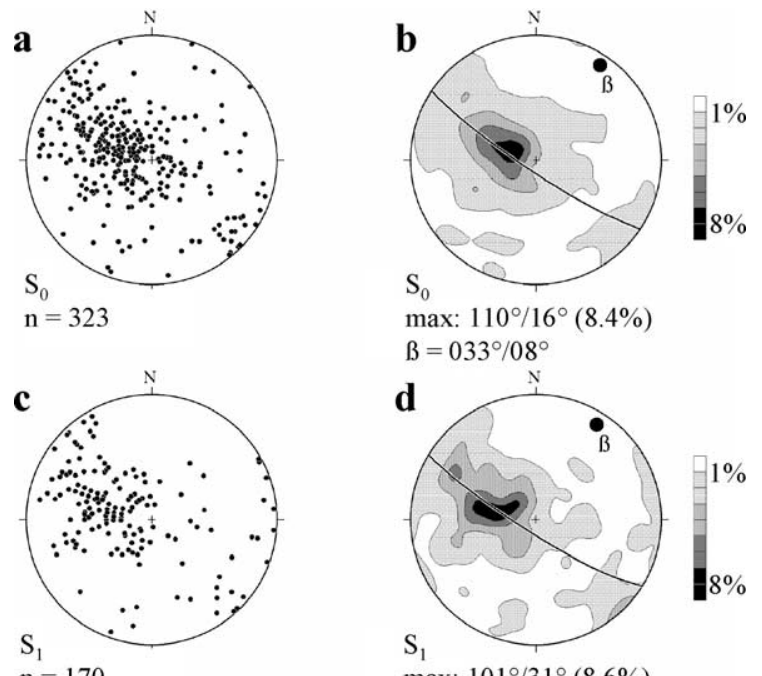

$\mathrm{n}=170$

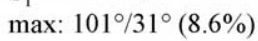

$$
\beta=031^{\circ} / 09^{\circ}
$$
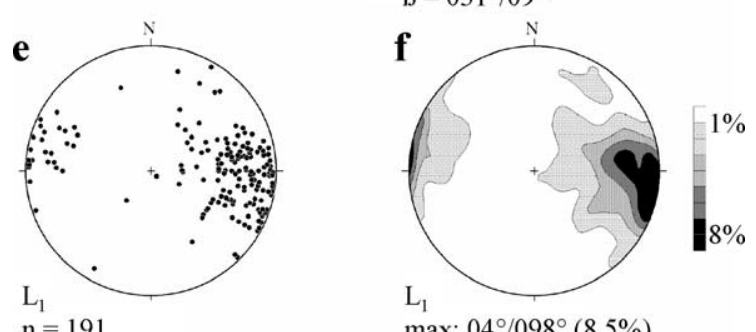

Fig. 7. Equal-area plots of indicated attitudes of $S_{0}, S_{1}$, and $L_{1}$ structural elements in the Chapada Acauã domain. (a) Poles to bedding. (b) Contoured equal-area plot of poles to bedding. $\beta$ defines the regional fold hinge trend (NNE). (c) Poles to $S_{1}$ schistosity. (d) Contoured equal-area plot illustrating that $S_{1}$ schistosity dips predominantly eastward, slightly more steeply than $\mathrm{S}_{0}$. (e) $\mathrm{L}_{1}$ mineral-stretching lineation. (f) Contoured equal-area plot of the $\mathrm{L}_{1}$ lineations, which are dominantly down-dip in respect to the $\mathrm{S}_{1}$ schistosity. schistosity in the Chapada Acauã domain dips east, subparallel to the domain's enveloping surfaces. Throughout the domain, 5-25-cm-thick milky white quartz veins developed parallel to $S_{1}$ foliation. Also, a prominent eastwest-trending mineral lineation, defined by stretched pebbles, tails on quartz grains, and streaks of mica (and in higher-grade schists, by aligned kyanite) developed on the surface of the $S_{1}$ foliation in phyllites and schists (Fig. 7e and $\mathrm{f}$ ). This lineation is also manifested by stretched quartz grains, which are visible on the surface of the $S_{1}$-parallel quartz veins.

In addition to the $F_{1}$ west-verging folds described above, outcrops in the Chapada Acauã domain contained inclined asymmetric folds that verge east and down dip, relative to the domain's enveloping surfaces. Isoclinal $F_{1}$ folds have been bent around the hinges of the east-verging folds, and thus we consider the east-verging set to be $F_{2}$ folds. The

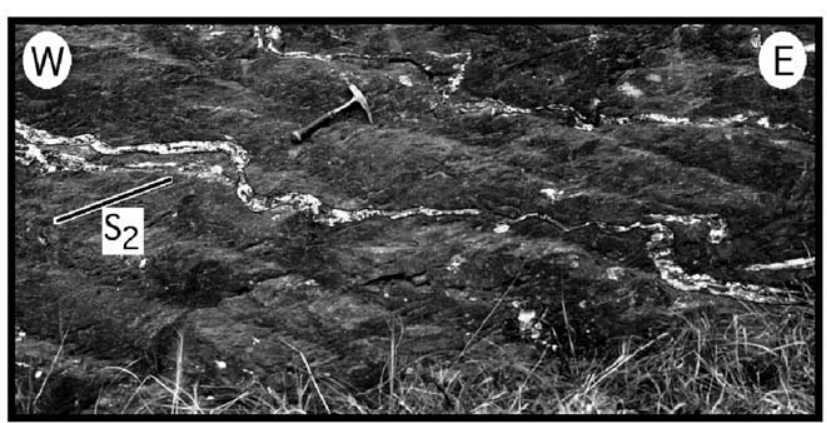

a

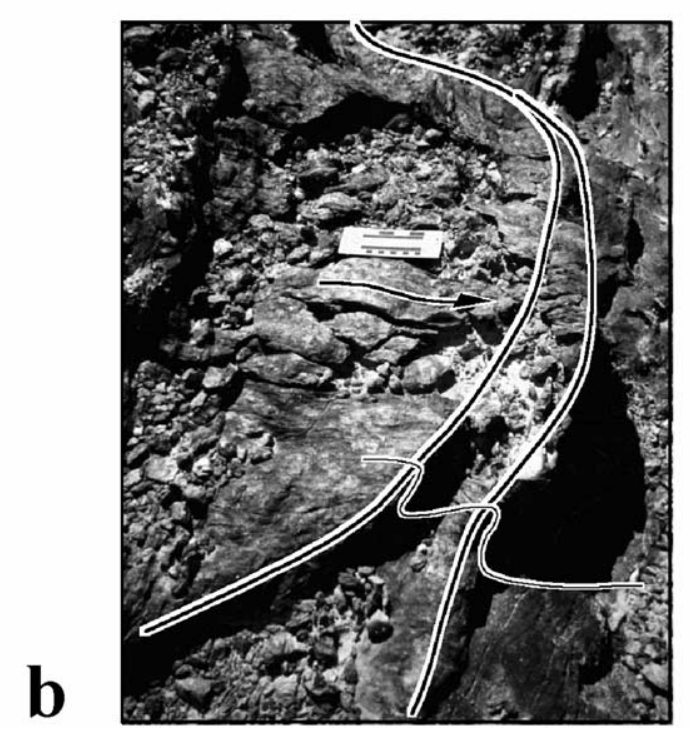

Fig. 8. (a) Photograph of $\mathrm{F}_{2}$ folds involving a quartz vein that itself lies parallel to the $\mathrm{S}_{0} / \mathrm{S}_{1}$ plane. The cascade of folds visible here indicates topdown-to-the-east shear within east-dipping enveloping surfaces. The labeled $S_{2}$ cleavage is axial-planar to the $F_{2}$ folds. (b) Oblique photo of an $\mathrm{F}_{2}$ fold, exposed in 3-D, illustrating how its hinge displays a convex curve in the direction of transport. The arrow indicates the transport lineation on the foliation surface. Note that the fold hinge bifurcates along its trend, from the background to the foreground of the photo. 
shape of $F_{2}$ folds is defined by traces of $S_{0} / S_{1}$ foliation in pelitic schists, by traces of the quartz veins that parallel $S_{1}$, and locally, by traces of relict quartzite beds (Fig. 8a). $F_{2}$ folds occur in cascading trains whose enveloping surfaces parallel the enveloping surfaces of the domain as a whole. They are asymmetric and vary in profile from open, in which the short limb is upright, to tight, in which the short limb is vertical, to nearly isoclinal, in which the short limb is overturned. In general, hinges of $\mathrm{F}_{2}$ folds trend along the
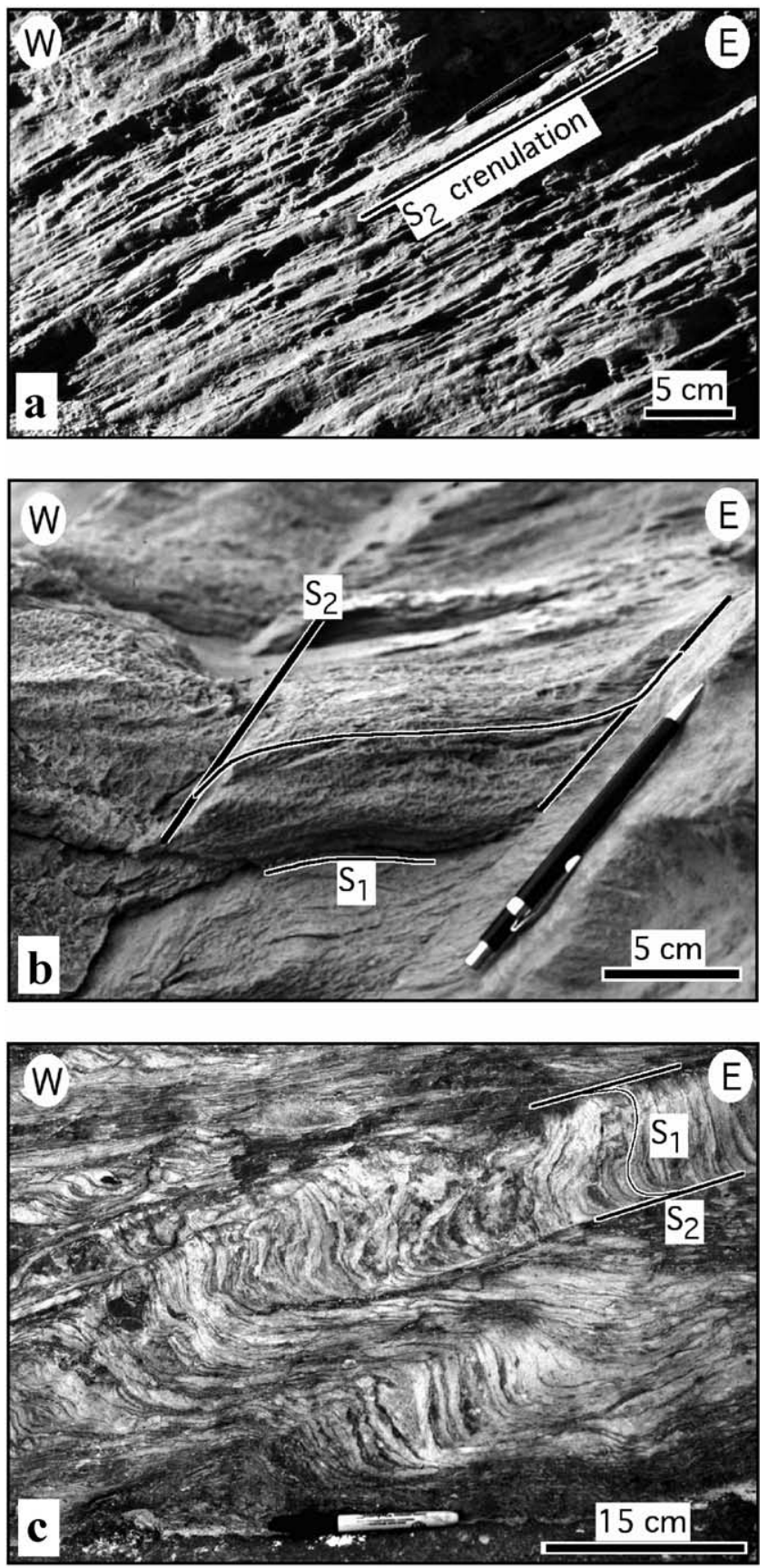

Fig. 9. Photographs of $S_{2}$ crenulation cleavage. (a) Closely spaced domains with moderate dip. (b) Steeply dipping domains in which $S_{1}$ has an open sigmoid shape. (c) Widely spaced domains with a shallow dip and tight sigmoid shape. strike of the Chapada Acauã domain. But locally, $F_{2}$ fold hinges display a pronounced curvature in map view, bowing down regional dip in the direction of vergence. We found a few examples of $F_{2}$ fold hinges that curve through almost $180^{\circ}$; folds and such hinge shapes can be considered to be sheath folds. The axis of symmetry of sheath folds in the Chapada Acauã domain trends east, down the regional dip (Fig. 8b).

The orientation and geometry of $\mathrm{F}_{2}$ folds indicates that they formed in a top-down-to-the-east (i.e. normal-sense) shear couple. Quartzite beds locally occur interlayered with metadiamictites and phyllites of the Chapada Acauã domain, and these beds preserve sedimentary structures. We observed that, on the long limbs of $F_{2}$ folds, cross lamination in quartzite indicates that the beds are right-sideup. Therefore, the $\mathrm{F}_{2}$ folds of the Chapada Acauã domain are not parasitic folds formed from the overturned limb of a regional-scale nappe.

The most striking difference between the fabric of the Serra do Espinhaço domain and that of the Chapada Acauã domain is that the latter includes a pervasive asymmetric crenulation cleavage (Uhlein et al., 1986; Uhlein, 1991; Del Rey-Silva et al., 1995; Grossi Sad et al., 1997; Fig. 9a-c). The crenulation cleavage of the Chapada Acauã domain is superimposed on, and results in bending of, $\mathrm{S}_{1}$ schistosity. Thus, we consider it to be the $S_{2}$ fabric of the domain (Fig. $11 \mathrm{~b}$ and c). Significantly, $S_{2}$ crenulation is axial-planar to the east-verging $\mathrm{F}_{2}$ folds, so $\mathrm{S}_{2}$ planes dip west, antithetic to the dip of the Chapada Acauã domain's enveloping surfaces (Fig. 10a and b). A lineation defined by the crests of crenulations parallels the overall structural grain of the domain (Fig. 10c and d).
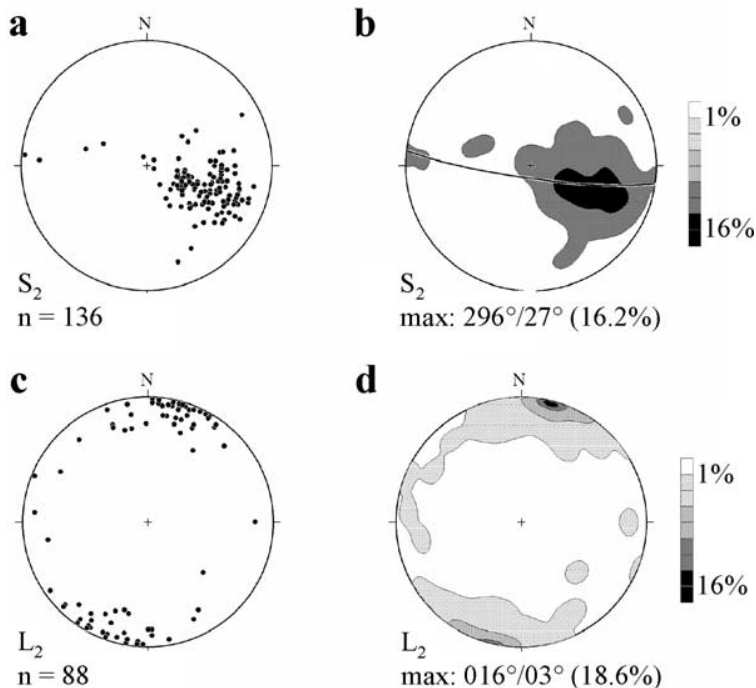

Fig. 10. Equal-area plots of indicated attitudes of $\mathrm{S}_{2}$ and $\mathrm{L}_{2}$ structural elements in the Chapada Acauã domain. (a) Poles to $S_{2}$ asymmetric crenulation cleavage. (b) Contoured equal-area plot illustrating that $S_{2}$ dips predominantly to the west, at a range of dips. (c) $\mathrm{L}_{2}$ crenulation lineations. (d) Contoured equal-area plot illustrating that the $\mathrm{L}_{2}$ crenulation lineations trend parallel to the local structural traces of the Araçuaí Orogen. 
In detail, $\mathrm{S}_{2}$ cleavage surfaces consist of narrow (1-5mm-thick) bands in which mica has completely transposed into parallelism with the $S_{2}$ plane. The $S_{2}$ domains bound $5 \mathrm{~mm}$ - to $10 \mathrm{~cm}$-wide microlithons, in which $\mathrm{S}_{1}$ foliation remains visible but has been folded into a sigmoid shape in profile. Sigmoid shapes in microlithons vary. In locations with steeply dipping $S_{2}$ crenulation, sigmoids are open (Fig. 9b), whereas in locations with gently dipping crenulation, the sigmoids are tight, with relict $S_{1}$ planes overturning, relative to their original dip, in the center of each microlithon (Fig. 9c). This relation suggests that, as strain increases, the $S_{2}$ cleavage rotates to a shallower dip and the $S_{1}$ sigmoids in microlithons become flattened. The sigmoid shape of $S_{1}$ traces in microlithons suggests that shear occurred along $S_{2}$ cleavage planes (Twiss and Moores, 1992). Correlation of marker layers (quartzite streaks in the $S_{0} / S_{1}$ foliation plane) across $S_{2}$ domains indicates that shear displacements on $S_{2}$ domain surfaces range from $1 \mathrm{~mm}$ to $20 \mathrm{~cm}$. With few exceptions (discussed later), the geometry of sigmoids within the microlithons indicates a top-down-to-the-west sense of shear on individual domain surfaces.

Crenulation cleavage similar in character to the $S_{2}$ fabric of the Chapada Acauã domain has been found in other locations worldwide, and has been discussed by numerous researchers. Because of the shape of relict $S_{1}$ cleavage in microlithons, the $S_{2}$ cleavage of the Chapada Acauã domain can be called an 'asymmetric crenulation cleavage' (Twiss and Moores, 1992). Because $S_{1}$ remains visible within microlithons of $\mathrm{S}_{2}$ crenulation, and because complete redistribution of elements did not occur during the development of $S_{2}$ (with some exceptions discussed later), the cleavage can also be called a 'zonal crenulation cleavage', following the terminology of Gray (1977a,b, 1979a,b) (see also Rickard, 1961; Gray and Durney, 1979a,b; Marlow and Etheridge, 1977).

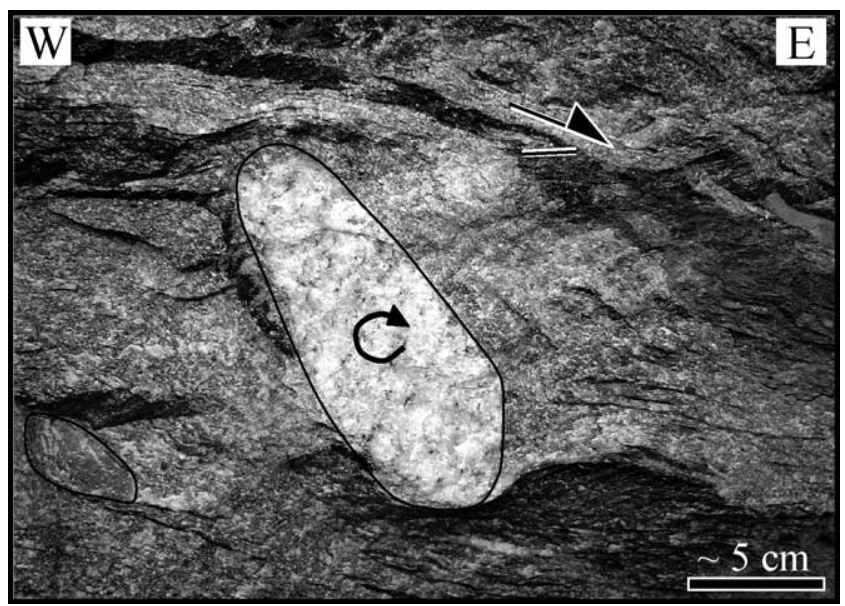

Fig. 11. Photo of rotated clasts in the Macaúbas Group of the Chapada Acauã domain. The clast, together with its pressure-shadow tails, defines a sigmoid shape, indicating top-down-to-the-east shear. The geometry of relict $S_{1}$ cleavage in a pelitic lens $S_{0}$, supports this proposal.
Development of the $S_{2}$ crenulation in the Chapada Acauã domain affected the geometry of stretched and flattened pebbles and cobbles in Macaúbas metadiamictites. Specifically, clasts of weaker rock types, along with their tails, have been contorted into sigmoidal shapes that mimic the profile of $S_{1}$ foliation within $S_{2}$ microlithons. Resistant quartzite and gneiss clasts in the Chapada Acauã domain, however, are not flattened significantly. Disruption of the matrix fabric around resistant clasts suggests that these clasts rolled during formation of $\mathrm{S}_{2}$, in a top-down-to-theeast shear couple (Fig. 11).

At several localities within the Chapada Acauã domain, we observed west-dipping normal-sense shear zones (Fig. 12a). These shear zones roughly parallel the $S_{2}$ foliation, suggesting that they are kinematically related, but they

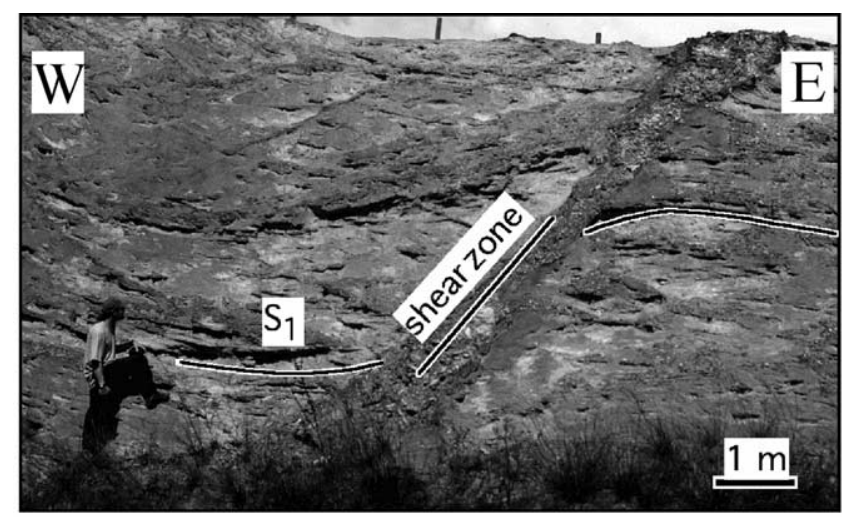

$\mathbf{a}$

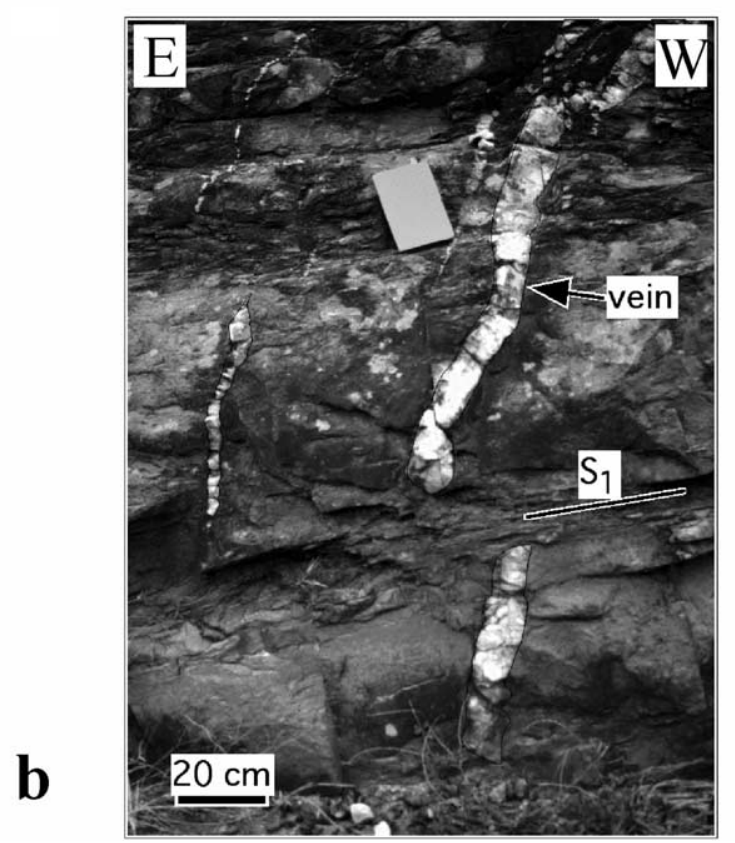

Fig. 12. (a) Photograph showing a late-stage normal sense shear zone, displacing the $S_{1}$ foliation. The displacement on this example is about $3 \mathrm{~m}$. A thin breccia occurs locally along the shear zone. (b) Photograph of quartz extension gashes, formed in a relatively rigid meta-sandstone layer. Note that they are almost vertical. This photo was taken looking south, so East is on the left. 
are marked by $10-15-\mathrm{cm}$-wide bands of a micro-brecciated rock, and they accommodate significantly more displacement (up to $5 \mathrm{~m}$ ) than do individual $\mathrm{S}_{2}$ cleavage domains. Shear-zone dips vary-the amount of displacement across the shear zones increases as the dip of the shear zone decreases. Locally, these shear zones are spaced at intervals of 2-20 m. Outcrops in the Chapada Acauã domain also expose a generation of non-bedding-parallel quartz veins cuts the quartzite beds (Fig. 12b). These veins taper to their tips, and occur in an en échelon configuration, suggesting that they originated as tension gashes in a shear couple associated with top-down-to-the east movement. Their dip ranges from $60^{\circ} \mathrm{W}$ to vertical. In places, the veins have been cut by mesoscopic east-dipping bed-parallel shear surfaces. Offset across these surfaces indicates top-down-to-the-east displacement.

As noted above, the $S_{2}$ crenulation of the Chapada Acauã domain generally dips westward and displays top-down-tothe-west shear on individual cleavage-domain surfaces. However, we observed that $S_{2}$ cleavage attitude, as well as the sense of shear on $S_{2}$ domains, as indicated by the sigmoid geometry of $S_{1}$ in microlithons, is different in locations where meta-sediments of the domain lie in proximity to basement contacts that do not dip east. Field relations at two localities along the northern margin of the Guanhães block, a 100-km-wide basement high at the southern end of our study area, illustrate this point (Fig. 4a).

First, near the town of Senador Modestino (locality SM on Fig. 4a), a local north-south-trending basement high occurs. Here, the surface of the Archean granitoid rises to a shallower depth. Roadcuts and field exposures provide outcrops of Macaúbas Group schist just above the basement-schist contact. On the west side of the basement high, where the basement-cover contact dips west, $S_{2}$ cleavage in the schist maintains its westward dip, but the asymmetry in microlithons changes (Fig. 13) such that the sigmoid shape indicates top-up-to-the-east (i.e. reverse-sense) shear. Further, in some exposures, $S_{1}$ in microlithons does not have the profile shape of a sigmoid but rather resembles a simple arch or trough, and $\mathrm{S}_{2}$ cleavage is axial planar to east-verging $\mathrm{F}_{2}$ fold trains

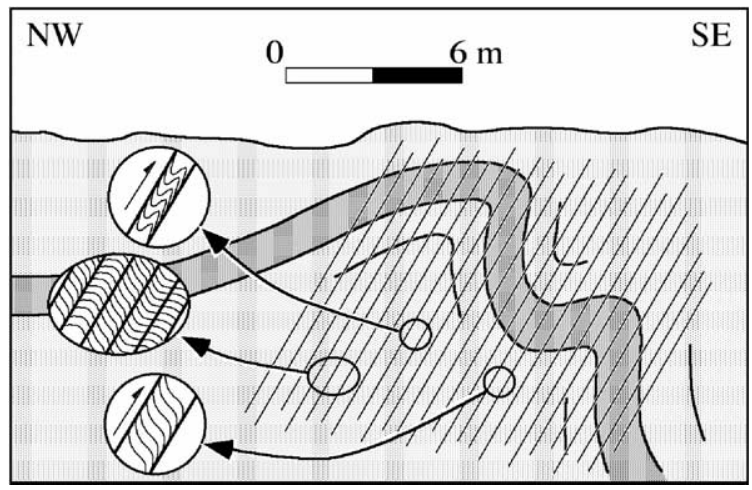

Fig. 13. Outcrop sketch illustrating the top-up-to-the-east (reverse-sense) shear indicated by the geometry of $S_{1}$ foliation within $S_{2}$ microlithons at the Senador Modestino locality. The darker shaded band is a marker layer. contained within west-dipping enveloping surfaces. The geometry of these folds and faults suggests that the presence of the Senador Modestino basement high localized a frontal thrust system on which rocks moved up and to the east. We envision this situation to resemble that which occurs at the base of a valley glacier that flows downslope overall, but locally must ride up and over a substrate high.

Farther to the northeast along the northern margin of the Guanhães block, the basement-cover contact dips northwest. Here, $S_{2}$ cleavage rotates to a northeast strike, parallel to the margin of the complex, and becomes more intense, meaning that cleavage domains are more closely spaced than elsewhere. In fact, adjacent to the basement-cover contact, the cleavage evolves into a 'domainal crenulation cleavage' (terminology of Gray (1977a,b)) subparallel to the contact-cleavage domains here have evolved into nearly pure bands of mica, microlithons have evolved into nearly pure bands of quartz, and $\mathrm{S}_{1}$ has been totally transposed into $S_{2}$. Where this occurs, $F_{2}$ folds are isoclinal, with subhorizontal axial planes and steep plunges to the northwest. In these folds, $S_{2}$ locally becomes overprinted by an $S_{3}$ crenulation that is axial planar to $F_{3}$ folds whose hinges have a bearing of $330^{\circ}$. Mineral lineations within this region have attitudes of about $075^{\circ} / 20^{\circ}$. These observations indicate that at the southern end of our study area, the Chapada Acauã domain curves eastward and follows the basement-cover contact defining the northern margin of the Guanhães block. Along this contact, Macaúbas rocks of the domain moved parallel to the basement-cover contact, relative to the basement below.

\subsection{Structures of the Turmalina domain}

The Turmalina domain, named for a town within it, encompasses the entire region between the Chapada Acauã domain and the Mucuri granite province. It consists of three parts:

(1) High-grade Schist. The western part of the Turmalina domain, adjacent to the Chapada Acauã domain, consists of amphibolite-grade schists derived from the Macaúbas Group (Fig. 4a). These schists, which are mediumgrained, contain muscovite, biotite, garnet, and quartz \pm kyanite and staurolite, have a strong schistosity, which dips eastward, and display a strong mineral-stretching lineation, which plunges eastwards. Relict $\mathrm{S}_{0}$ surfaces, represented by compositional contrasts between layers, outline west-verging tight to isoclinal, inclined folds in the schists. The asymmetry of these folds indicates topup-to-the-west (reverse-sense) displacement. Schistosity in this domain is axial-planar to these folds in their hinges, where it cross cuts $S_{0}$, but it lies parallel to $S_{0}$ on fold limbs.

(2) Salinas Basin. The eastern part of the Turmalina domain exposes the relict of a basin in which the Salinas Formation, a sequence of sandy turbidites intercalated 
with conglomerates, was deposited. Salinas strata have been metamorphosed only to lower greenschist grade, and thus are significantly lower grade than rocks in the western part of the Turmalina domain. Also, they have not been as intensely deformed as the schist in the western part of the domain - they occur in homoclinally E-dipping panels and display only a weak spaced cleavage.

(3) Minas Novas Corridor. In the southern portion of the Turmalina domain, near the town of Minas Novas, Pedrosa-Soares (1995) identified a northeast-trending belt of Macaúbas Group strata in which bedding has a northeast strike and a steep dip. An oblique mineral lineation that plunges gently to the northeast can be seen on $S_{1}$ and $S_{0}$ surfaces (Fig. $4 a$ ). Here, $S_{0}$ is folded around plunging asymmetric folds. The geometry of these folds, along with the shallow rake of mineral lineations, indicates that overall movement in this belt was reverse-dextral. To emphasize its distinctive kinematics, Pedrosa-Soares (1995) named this belt the 'Minas Novas Corridor'.

Along its eastern border, rocks of the Turmalina domain have been intruded by plutons of the Mucuri granite province. Foliation trends in wall rocks near plutons have been deflected into parallelism with pluton borders, and thus no longer retain regional patterns. The kinematics of deformation within the Mucuri granite province remains largely unknown. Of note, rocks throughout the Turmalina domain, both within and outside of the Minas Novas Corridor, do not contain the previously described westdipping $\mathrm{S}_{2}$ crenulation or $\mathrm{F}_{2}$ folds.

\section{Discussion and interpretation}

The Araçuaí orogen of eastern Brazil formed in Late Neoproterozoic/Early Paleozoic time, due to convergence between the São Francisco and Congo cratons. We divide the western portion of the Araçuaí orogen, between $16^{\circ} \mathrm{S}$ and $18^{\circ} \mathrm{S}$, into three north-south-trending structural domains (named, from west to east: the Serra do Espinhaço domain, the Chapada Acauã domain, and the Turmalina domain). Field studies indicate that the sense of shear recorded by structures in the Chapada Acauã domain differs from that of the other domains. Also, the Chapada Acauã domain contains a pervasive asymmetric crenulation cleavage not found in the other domains. Below, we present a kinematic and tectonic interpretation of the Chapada Acauã domain, and discuss the role that crenulation cleavage played during its evolution.

\subsection{Kinematics of deformation in the western Araçuai orogen: existence of the CASZ}

The Serra do Espinhaço domain of the Araçuaí orogen is a fold-thrust belt in which top-up-to-the-west (i.e. reverse-

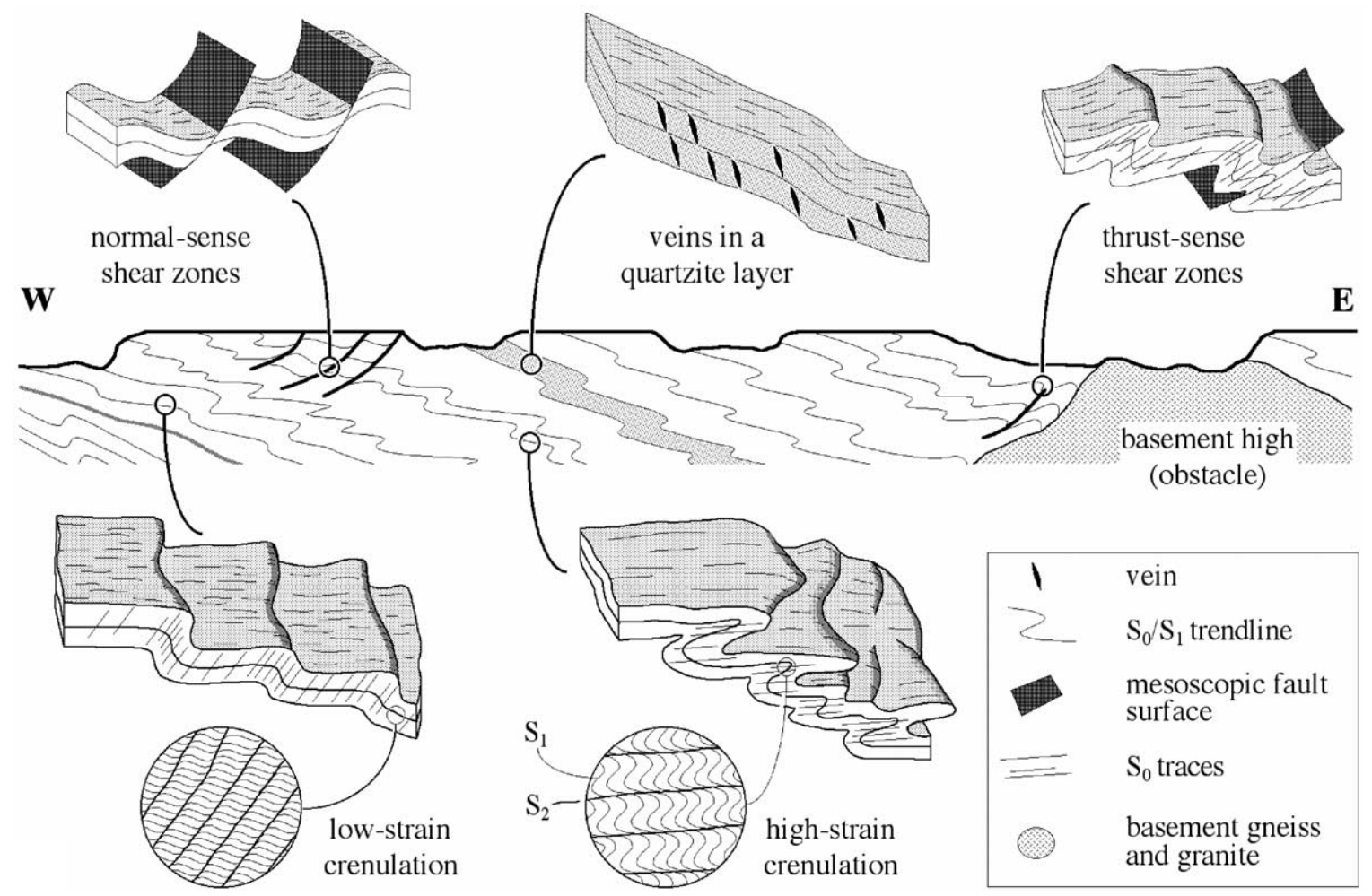

Fig. 14. Synoptic image showing structural elements in the Chapada Acauã domain. The cross-section schematically represents the width of domain between the east edge of the Serra do Espinhaço fold-thrust belt and the basement high at Senador Modestino. 
sense) displacement occurred on east-dipping faults. Folds $\left(\mathrm{F}_{1}\right)$ in the Serra do Espinhaço domain verge west, and strata in these folds contain an east-dipping phyllitic cleavage $\left(S_{1}\right)$. The Chapada Acauã domain, which lies on the hinterland side of the Serra do Espinhaço domain, is an east-dipping belt of pelitic schist, quartzite, and metadiamictite. Pelitic schist and metadiamicton in the Chapada Acauã domain display the consequences of a second deformation event $\left(\mathrm{D}_{2}\right)$, not found in the Serra do Espinhaço domain. This second deformation event produced a suite of structures that includes (Fig. 14): a cascade of top-down-to-the-east folds $\left(F_{2}\right)$; vertical en échelon tension gashes within east-dipping enveloping surfaces; rotated clasts with a sense of rotation compatible with top-down-to-the-east (i.e. normal-sense) shear; and mesoscopic normal-sense shear zones. Based on the existence of these features, we propose that the Chapada Acauã domain is a regional-scale normal-sense shear zone, which we henceforth refer to as the Chapada Acauã shear zone (CASZ).

Could the CASZ have formed to accommodate shear in the overturned limb of a regional-scale west-verging nappe?
We discount this hypothesis because we found no evidence for regional-scale repetition of stratigraphic units in the domain, and no evidence for regional-scale fold closure. Further, stratigraphic facing indicators preserved in quartzite indicate that, overall, beds in the CASZ are right-side-up.

We have traced the CASZ along the hinterland margin of the Espinhaço fold-thrust belt (Fig. 15). At its north end, the CASZ merges with a northwest-trending strike-slip shear zone. From this intersection southwards, to $18^{\circ} \mathrm{S}$, the CASZ was a frontal ramp during normal-sense shear, for in this portion schists and metadiamictites display a pervasive down-dip lineation. At $18^{\circ} \mathrm{S}$, the CASZ curves and trends easterly along the north end of the Guanhães basement high, and the schist contains north-plunging folds and a northeastplunging lineation. These relations imply that, at its southern end, the CASZ becomes a lateral ramp that fringes the northern margin of the Guanhães basement high.

We have not mapped the CASZ south of $18^{\circ} \mathrm{S}$. But studies by others along the eastern and southeastern margin of the Guanhães basement high, studies within the Guanhães
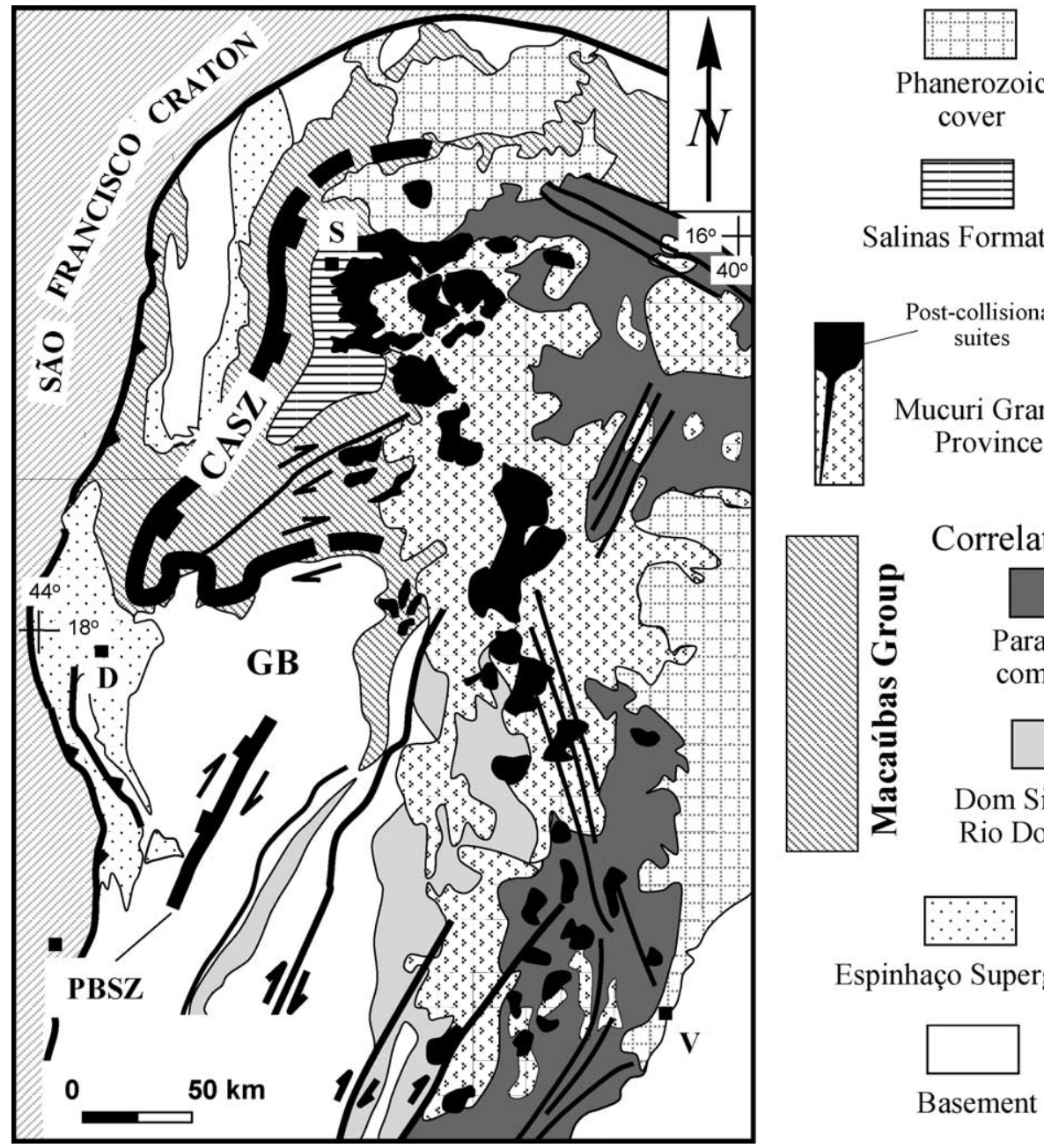

Salinas Formation
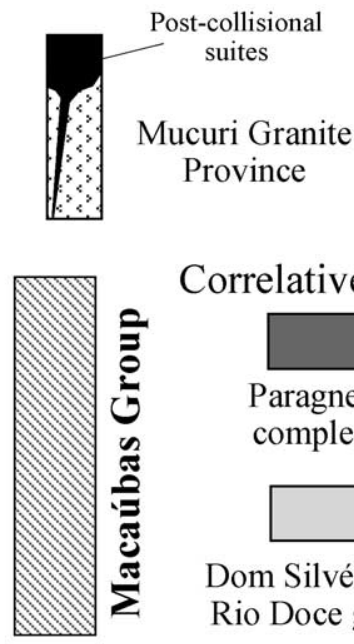

\section{Correlative units}

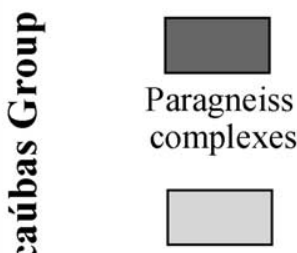

Dom Silvério and Rio Doce groups

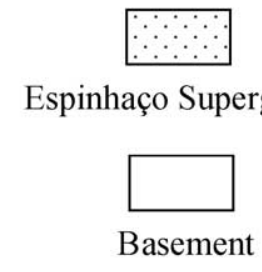

Fig. 15. Regional map illustration of the location of the Chapada Acauã Shear Zone (CASZ) relative to other structural elements of the Araçuaí orogen. GB= Guanhães basement block; PBSZ = Pedra Branca shear zone. Cities: $\mathrm{S}=$ Salinas; $\mathrm{D}=$ Diamantina; V $=\mathrm{Vitó}$ (ia. 
block, indicate that normal-sense shear zones do occur south of $18^{\circ} \mathrm{S}$ (Cunningham et al., 1996; Peres et al., 2004). Examples include the Pedra Branca shear zone and a series of emerald-bearing shear zones in the Guanhães block (Fig. 15). Significantly, radiometric dates from the emeraldbearing shear zones suggest that they were active at about $500 \mathrm{Ma}$, near the end of the Brasiliano orogeny (Peres et al., 2004).

\subsection{Tectonic role of the CASZ: an extensional detachment during orogenic collapse}

Based on the location of the CASZ, and the kinematics of shear within it, we conclude that the CASZ is a regionalscale normal-sense shear zone (extensional detachment) that accommodated displacement of the internal portion of the Araçuaí orogen relative to its foreland. Down-dip-verging $\mathrm{F}_{2}$ folds within the CASZ refold up-dip-verging $\mathrm{F}_{1}$ folds, so the normal-sense shear is syn- to post-Brasiliano thrusting.
Indeed, since the CASZ is parallel to thrusts in the Espinhaço fold-thrust belt, the structure could represent inversion of a preexisting thrust. The CASZ cannot be associated with Cretaceous or younger South Atlantic rifting, because faults associated with these events only occur far to the east of the CASZ, and such faults are defined by zones of brittle fault breccia whose existence is not compatible with the level of exposure of the CASZ. Thus, we conclude that the CASZ was active during the late stage of the Brasiliano orogeny. This conclusion is compatible with dates of $500 \mathrm{Ma}$ from normal-sense shear zones along strike to the south.

The existence of late-Brasiliano extensional detachment (the CASZ) in the Araçuaí orogen is compatible with a tectonic model in which the final stage of the orogen's evolution involved extensional collapse. During collapse, displacement on the CASZ could have contributed to the exhumation of mid-crustal rocks in the interior of the orogen, and possibly to 'channel flow' of mid-crustal rocks
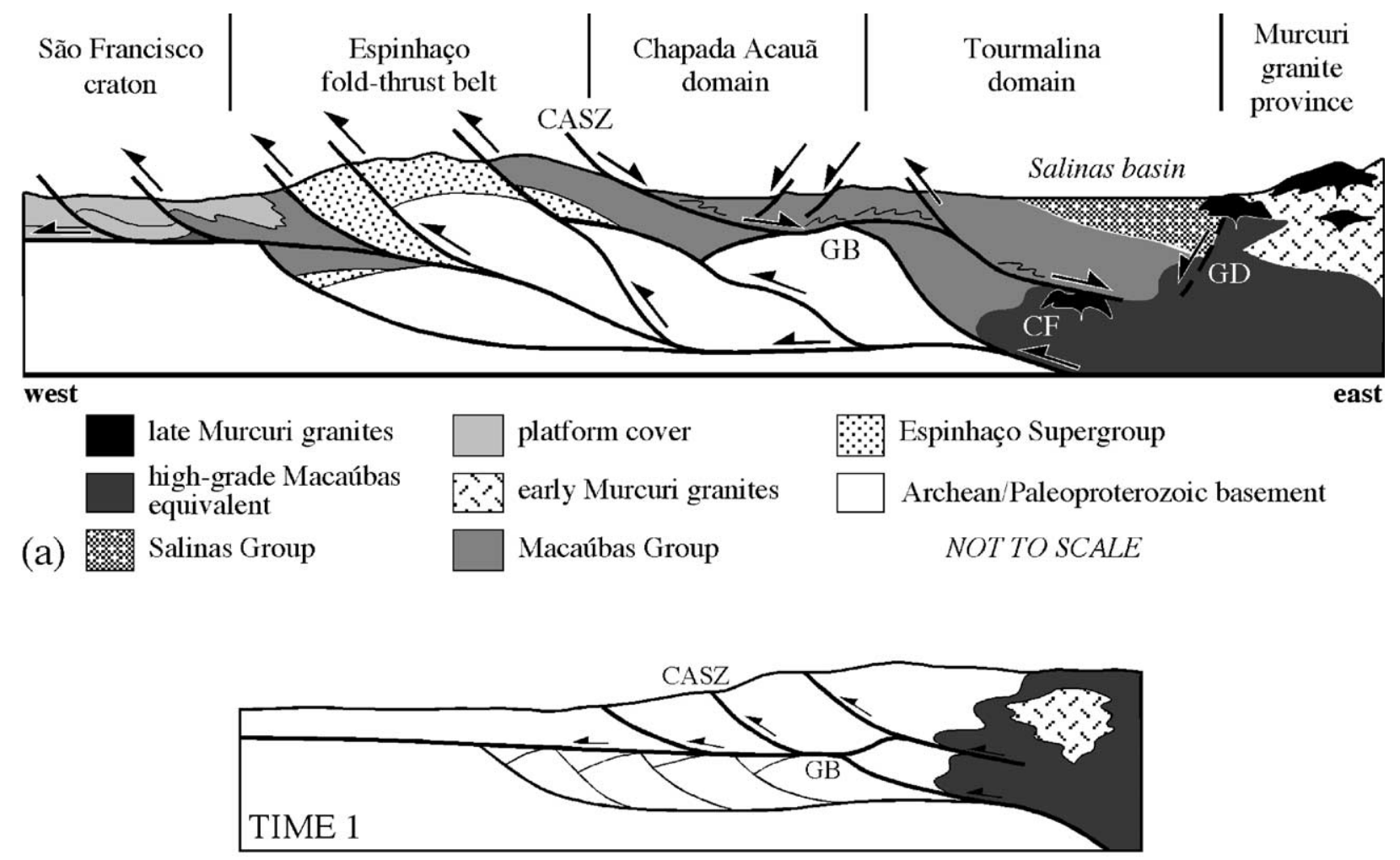

(b)

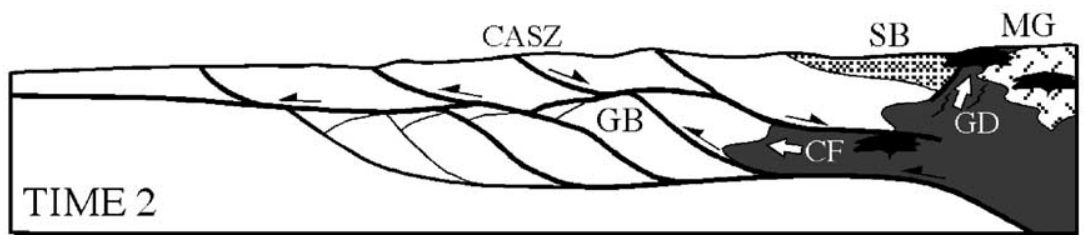

Fig. 16. (a) Speculative cross-sectional model showing the relationship among the CASZ, the Espinhaço fold-thrust belt, the Salinas Formation (the fill of an extensional intramontane basin?), the Guanhães block, and the Mucuri granite province. In this model, the CASZ is an inverted thrust fault. (b) Cross-section sketches indicated two stages in the evolution of the Araçuaí orogen during the proposed collapse phase. 
toward the foreland (Fig. 16a and b; cf. Beaumont et al., 2001).

In some cases, an extensional detachment dips toward the hinterland, and thus is 'synthetic' relative to thrusts on its foreland side, whereas in other cases, it dips toward the foreland, and thus is 'antithetic' relative to the thrusts on its foreland side (cf. Collettini and Barchi, 2002; Vanderhaeghe et al., 2003). Considering its geometry, we suggest that the CASZ is a synthetic extensional detachment, and thus resembles the South Tibet Detachment. Notably, the CASZ differs from the South Tibet detachment in that it is not mylonitic, but rather contains low-grade, crenulated schists. Thus, the CASZ may serve as an example of what an extensional detachment looks like at shallower crustal levels than are currently exposed along the South Tibet detachment (cf. Zheng et al., 2004).

The proposal that a phase of orogenic collapse occurred at the end of the Brasiliano orogeny could explain three enigmatic features of the Araçuaí orogen:

(1) Origin of the Salinas basin. Deposits of the Salinas Formation filled a basin in the Turmalina domain, west of the Mucuri granite province (Fig. 16). These deposits do not contain the metamorphic or deformational signatures of other units in the Araçuaí orogen, and they were deposited unconformably above deformed and metamorphosed units. Such characteristics typify deposits of intramontane basins formed during extensional collapse. The Salinas basin could have formed in this manner.

(2) Late-phase melting. Pedrosa-Soares and WiedemannLeonardos (2000) proposed that a late phase of intrusion occurred in the Mucuri granite province at 520$490 \mathrm{Ma}$. They relate this phase of post-collisional intrusion to decompression. Extensional collapse of the Araçuaí orogen could have caused the decompression that triggered production of late granitic melts.

(3) Core-complex characteristics of the Guanhães block. The Guanhães block is a basement high composed of Archean and Paleoproterozoic granite and high-grade gneiss, which is surrounded by younger rocks. Our structural analysis suggests that the CASZ is a detachment that separates younger schist of the hanging wall from older basement rocks of the footwall. Thus, normal-sense shear on the CASZ could have contributed to exhumation of the Guanhães block. In this context, the block may be viewed as a 'metamorphic core complex', if we define a core complex simply as an exposure of a regional-scale extensional detachment and of the footwall beneath it. We emphasize that, by using the term 'core complex', we do not imply that structures at the surface of the Guanhães block resemble those of classic metamorphic core complexes of the southwestern United States (Compton, 1980; Coney and Harms, 1984; Spencer, 1984; Davis et al., 1986; Malavieille, 1987). For example, the Guanhães block does not have a carapace of mylonite overlain by chlorite breccia zone and by tilted fault blocks bounded by brittle normal faults. Notably, however, rocks of the Guanhães block underwent migmatization between 530 and $500 \mathrm{Ma}$ (Machado et al., 1989; Silva et al., 2002; Noce et al., 2003), i.e. during the post-collisional stage of the Brasiliano orogeny in the Araçuaí orogen. Similar migmatization has happened in other core complex examples (e.g. the Shuswap terrane of Canada; Whitney et al., 2004).

\subsection{Interpretation of asymmetric extensional crenulation cleavage in the CASZ}

Rocks in the Chapada Acauã domain contain a pervasive asymmetric extensional crenulation cleavage $\left(\mathrm{S}_{2}\right)$ that is axial planar to $F_{2}$ folds. In cases where outcrop faces are oblique to strike, interpretation of such cleavage can be misleading (Bell and Rubenach, 1983; Behrmann, 1987; Bell and Johnson, 1992; Lexa et al., 2004). However, because the $\mathrm{S}_{2}$ cleavage of the CASZ is so widespread and we have seen it on outcrop faces of many orientations, we are confident that we are not basing our interpretations on oblique sections. As noted earlier, $\mathrm{S}_{2}$ dips westward, and thus is antithetic to the east-dipping enveloping surfaces of the CASZ. (Similar geometries of cleavage may occur in the Appalachians; cf. De Roo and Van Staal, 1994.) Further, the sigmoid shapes defined by the trace of relict $\mathrm{S}_{1}$ schistosity in $\mathrm{S}_{2}$ microlithons indicate top-down-to-the-west slip on each $\mathrm{S}_{2}$ domain plane. When did this cleavage form, and what role, if any, did it play during motion on the CASZ? To answer this question, we first examine ways in which asymmetric crenulation cleavage can form, in general (Cosgrove, 1976; Platt, 1979, 1984; Bell and Rubenach, 1980; Platt and Vissers, 1980; Bell, 1981; White et al., 1981; Dennis and Secor, 1987; Passchier, 1991; Twiss and Moores, 1992; Passchier and Trouw, 1996):

(1) Oblique shortening. Crenulation cleavage can develop due to shortening of a previously foliated rock when the shortening direction trends at an angle to the preexisting foliation. If this mechanism applies to our study area, it would imply that asymmetric crenulation developed during the progressive regional shortening of the Araçuaí orogen that accompanied development of the Espinhaço fold-thrust belt.

(2) Rotation of symmetric crenulation. Crenulation cleavage can develop by rotation of a preexisting symmetric crenulation cleavage, so that shear occurs on crenulation domains after they first formed. This may happen when the rock layer containing the crenulation undergoes shear.

(3) Shear. Crenulation cleavage can develop as a 'shearband cleavage'. By using this genetic term, researchers imply that shear displacement occurs on each cleavage 
domain. If cleavage development accommodates layerparallel shortening of the layer in which it forms, the cleavage is a 'contractional crenulation cleavage', or $\mathrm{CCC}$, whereas if development results in extension of the layer in which it forms, then the cleavage is an 'extensional crenulation cleavage', or ECC (Platt, 1979,; 1984; Platt and Vissers, 1980). Both CCC and ECC can occur in conjugate sets. ECC has been identified in shear zones at many localities, where it typically crenulates a mylonitic foliation and lies at an angle to the enveloping surfaces of the shear zone. If the acute angle between ECC domains and the enveloping surface of the shear zone opens in the direction of shear, then the cleavage is a 'synthetic ECC', whereas if the acute angle opens opposite to the direction of shear, it is an 'antithetic ECC'; synthetic ECC tends to be more common (Zheng et al., 2004). Determination of the amount of shear across a shear-band cleavage can be difficult, because if volume loss occurs due to pressure solution in the cleavage domain, oblique shortening across a domain may produce an apparent offset (Gray and Durney, 1979a,b; Worley et al., 1997). Once formed, crenulation cleavage domains act as material planes in a rock, and thus can become active again during a later phase of deformation (Bell, 1986; Davis, 1995; Ham and Bell, 2004).

We propose that the $S_{2}$ asymmetric crenulation cleavage in the CASZ can be interpreted in three ways. First, the $S_{2}$ cleavage is entirely a synthetic extensional crenulation cleavage (ECC) related to top-up-to-the-west shear. If this were the case, then the cleavage formed completely during the phase of regional shortening that yielded the westverging Espinhaço fold-thrust belt, and was not affected by normal-sense shear reactivation of the CASZ. Second, the $\mathrm{S}_{2}$ cleavage initiated as a west-dipping ECC (associated
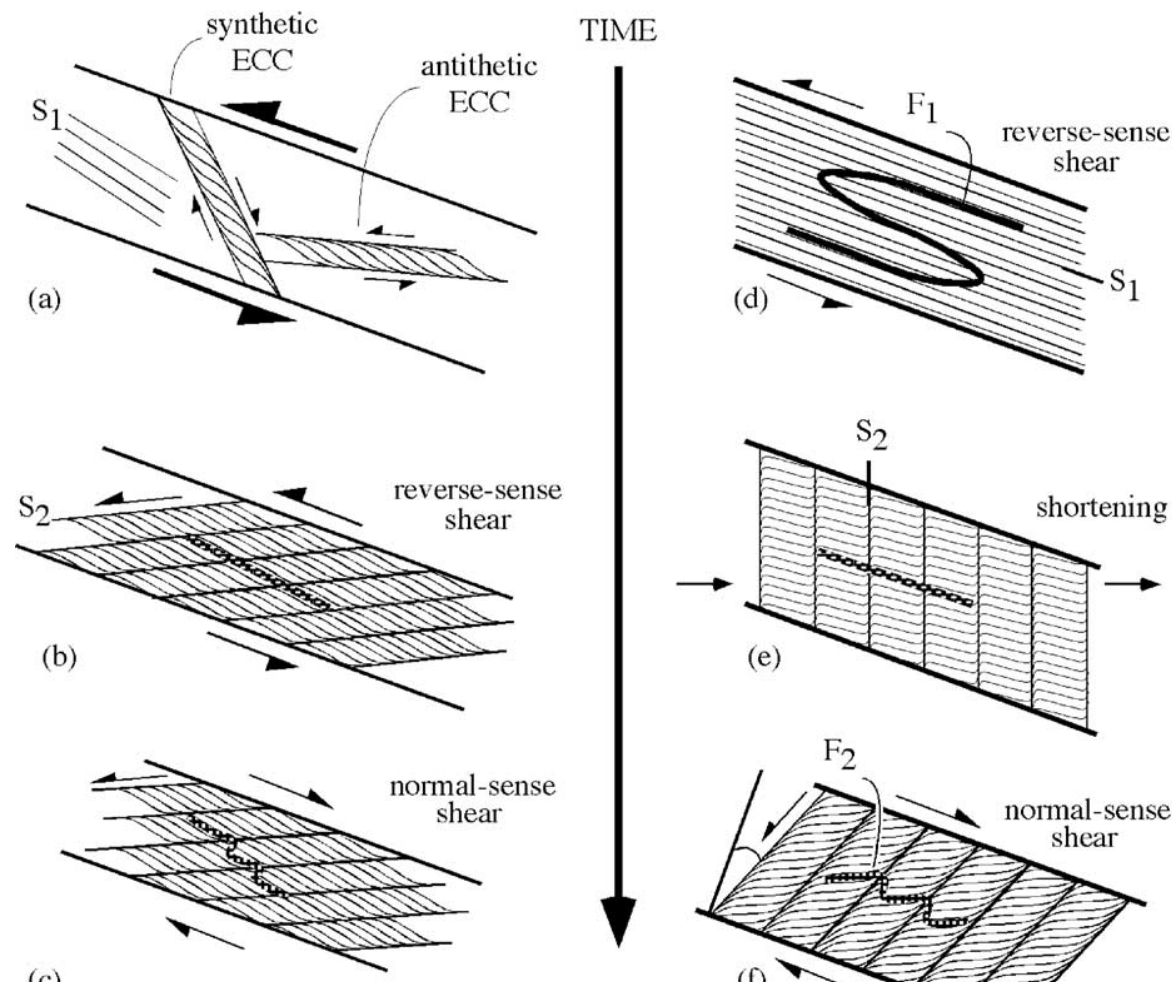

(c)
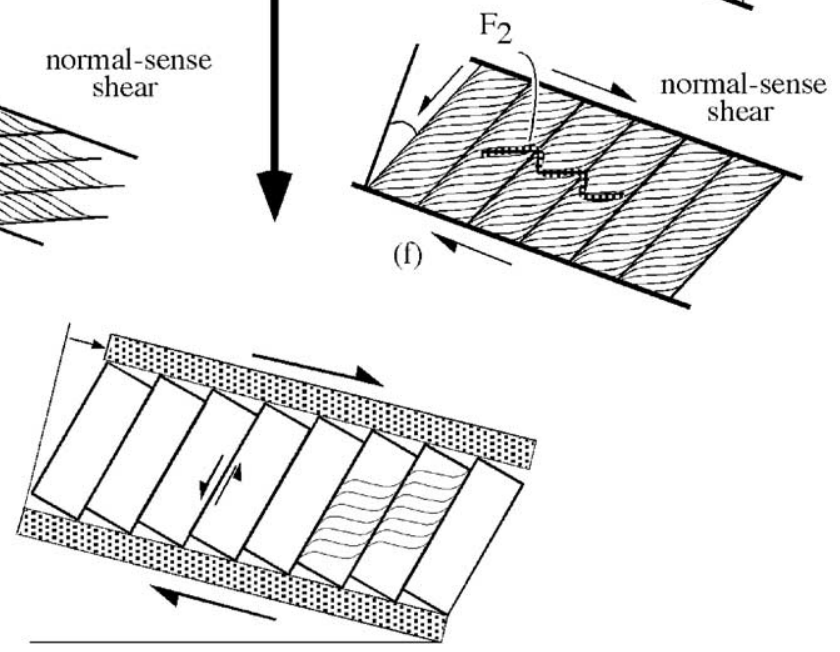

Fig. 17. Cross-sectional sketch illustrating two models of how development of the $S_{2}$ crenulation developed and is related to regional transport of hanging wall rocks down to the east. In stages (a)-(c), the cleavage starts as an antithetic ECC during thrusting, and then is reused during normal-sense shear. In (d)-(f), the cleavage starts as an vertical asymmetric crenulation formed during shortening at an angle to preexisting $\mathrm{S}_{1}$. In both models, cleavage domains serve the role of 'bookshelf normal faults', as the hanging wall of the CASZ moved down regional dip to the east, as shown in (g). 
with top-up-to-the-west shear), but during normal-sense shear in the CASZ, the cleavage reactivated, and crenulation domains rotated clockwise, as viewed looking along-strike to the north, and became axial planar to $\mathrm{F}_{2}$ folds as the folds developed (Fig. 17a-c). Third, the $\mathrm{S}_{2}$ cleavage initiated as a near-vertical asymmetric crenulation associated with eastwest shortening of a preexisting east-dipping schistosity. During normal-sense reactivation of the CASZ, the cleavage rotated clockwise, as viewed looking north, and became axial planar to $\mathrm{F}_{2}$ folds as the folds developed (Fig. 17d-f).

If either the second or third interpretation is correct, then the cleavage domains behaved like a mesoscopic bookshelf array of rotational normal faults when the CASZ was active (Fig. 17g). As such, evolution of the cleavage domains helped to accommodate both shear in the CASZ, and concomitant vertical shortening of the orogen (Bell et al., 2003).

Considering the range of present dips of $S_{2}$ cleavage, its pervasiveness, and the fact that it is axial-planar to a generation of folds, we think that the third interpretation, in which $\mathrm{S}_{2}$ cleavage initiated as a steep fabric, and then rotated into its present orientation during normal-sense shear in the CASZ, is the most likely to be correct. We do not think that the fabric is simply an ECC fabric (the first alternative interpretation), because such fabrics are generally not pervasive and are not axial-planar to a set of folds (Platt and Vissers, 1980)-we observed that the $\mathrm{S}_{2}$ crenulation cleavage of the CASZ is pervasive and is axial-planar to a generation of folds $\left(\mathrm{F}_{2}\right)$. Since cleavagedomain dips range from $>45^{\circ}$ to $<15^{\circ}$, we do not think that the second interpretation could apply, as we would expect the cleavage to have a shallower angle with respect to the CASZ than we observed.

\section{Acknowledgements}

This research was supported by NSF EAR 99-02730. F.F. Alkmim and A.C. Pedrosa-Soares received additional financial support from $\mathrm{CNPq}$ (Conselho Nacional de Desenvolvimento Científico e Tecnológico). We are very grateful for insightful reviews by Alain Chauvet and Tim Bell, and for helpful discussions with Tim Bell, Don Wise, and Christian Teyssier. Comments provided by Darrel Cowan, Jon Spencer and Brian Wernicke on an earlier version of the manuscript are also much appreciated. João Hippert provided very useful editorial input.

\section{References}

Alkmim, F.F., Marshak, S., Fonseca, M.A., 2001. Assembling West Gondwana in the Neoproterozoic: clues from the São Francisco Craton region, Brazil. Geology 29, 319-322.
Almeida-Abreu, P.A., Pflug, R., 1994. The geodynamic evolution of the southern Serra do Espinhaço, Minas Gerais, Brazil. Zentralblatt für Geologie und Paläontologie 1/2, 21-44.

Beaumont, C., Jamieson, R.A., Nguyen, M.H., Lee, B., 2001. Himalayan tectonics explained by extrusion of a low-viscosity crustal channel coupled to focused surface denudation. Nature 414, 738-742.

Behrmann, J.H., 1987. A precautionary note on shear bands as kinematic indicators. Journal of Structural Geology 9, 659-666.

Bell, T.H., 1981. Foliation development: the contribution, geometry and significance of progressive bulk inhomogeneous shortening. Tectonophysics $75,273-296$.

Bell, T.H., 1986. Foliation development and refraction in metamorphic rocks; reactivation of earlier foliations and decrenulation due to shifting patterns of deformation partitioning. Journal of Metamorphic Geology $4,421-444$.

Bell, T.H., Johnson, S.E., 1992. Shear sense; a new approach that resolves conflicts between criteria in metamorphic rocks. Journal of Metamorphic Geology 10, 99-124.

Bell, T.H., Rubenach, M.J., 1980. Crenulation cleavage developmentevidence for progressive bulk inhomogeneous shortening from millipede microstructures in the Robertson River Metamorphics. Tectonophysics 68, 9-15.

Bell, T.H., Rubenach, M.J., 1983. Sequential porphyroblast growth and crenulation cleavage develpoment during progressive deformation. Tectonophysics 92, 171-194

Bell, T.H., Ham, A.P., Hickey, K.A., 2003. Early formed regional antiforms and synforms that fold younger matrix schistosities: their effect on sites of mineral growth. Tectonophysics 367, 253-278.

Brito-Neves, B.B., Cordani, V.G., 1991. Tectonic evolution of South America during the Late Proterozoic. Precambrian Research 53, 23-40.

Brito-Neves, B.B., Campos-Neto, M.C., Fuck, R.A., 1999. From Rodinia to Western Gondwana: an approach to the Brasiliano-Pan African cycle and orogenic collage. Episodes 22, 155-166.

Burchfiel, B.C., Royden, L.H., 1985. North-south extension within the convergent Himalayan region. Geology 13, 679-682.

Burchfiel, B.C., Zhiliang, C., Hodges, K.V., Yuping, L., Royden, L.H., Changrong, D., Jiene, X., 1992. The South Tibetan detachment system, Himalayan orogen: extension contemporaneous with and parallel to shortening in a collisional mountain belt. Geological Society of America Special Paper 269. 41pp.

Campos-Neto, M.C., 2000. Orogenic systems from southwestern Gondwana. An approach to Brasiliano-PanAfrican Cycle and orogenic collage in south eastern Brazil. In: Cordani, U.G., Milani, E.J., Thomazfilho, A., Campos, D.A. (Eds.), Tectonic Evolution of South America 31st International Geological Congress, Rio de Janeiro, pp. 335-365.

Collettini, C., Barchi, M.R., 2002. A low-angle normal fault in the Umbria region (Central Italy): a mechanical model for the related microseismicity. Tectonophysics 359, 97-115.

Compton, R.R., 1980. Fabrics and strains in quartzites of a metamorphic core complex. Geological Society of America Memoir 153, 271-279.

Coney, P.J., Harms, T.A., 1984. Cordilleran metamorphic core complexes: Cenozoic extensional relics of Mesozoic compression. Geology 12, $550-554$.

Cosgrove, J.W., 1976. The formation of crenulation cleavage. Journal of the Geological Society of London 131, 155-178.

Cunningham, W.D., Marshak, S., Alkmim, F.F., 1996. Structural style of basin inversion at mid-crustal levels: two transects in the internal zone of the Brasiliano Araçuaí Belt, Minas Gerais Brazil. Precambrian Research 77, 1-15.

Cunningham, W.D., Alkmim, F.F., Marshak, S., 1998. A structural transect across the coastal mobile belt in the Brazilian Highlands (latitude $20^{\circ} \mathrm{S}$ ): the roots of a Precambrian transpressional orogen. Precambrian Research 92, 251-275.

Dalziel, I.W.D., 1997. Neoproterozoic-Paleozoic geography and tectonics: review, hypothesis, environmental speculation. Geological Society of America Bulletin 109, 16-42.

Davis, B.K., 1995. Regional-scale foliation reactivation and re-use 
during formation of a macroscopic fold in the Robertson River Metamorphics, North Queensland, Australia. Tectonophysics 242, 293 311.

Davis, G.A., Lister, G.S., Reynolds, S.J., 1986. Structural evolution of the Whipple and South Mountains shear zones, southwestern United States. Geology 14, 7-10.

De Roo, J.A., Van Staal, C.R., 1994. Transpression and extensional collapse: steep belts and flat belts in the Appalachian Central Mobile Belt, northern Brunswick, Canada. Geological Society of America Bulletin 106, 541-552.

Del-Rey Silva, L.H., Pedrosa-Soares, A.C., Fuck, R.A., 1995. Kinematic analysis in the Neoproterozoic Araçuaí belt, SE Brazil: tectonic implications for Gondwana assembly. Sociedade Brasileira de Geologia Núcleo de Minas Gerais, Boletim 13, 61-63.

Dennis, A.J., Secor, D.T., 1987. A model for the development of crenulations in shear zones with applications from the Southern Appalachian Piedmont. Journal of Structural Geology 9, 809-817.

Dewey, J.F., 1977. Extensional collapse of orogens. Tectonics 7, 1123-1139.

Dussin, I.A., Dussin, T.M., 1995. Supergrupo Espinhaço: Modelos de Evolução geodinâmica. Geonomos 3, 9-26.

Gray, D.R., 1977a. Morphologic classification of crenulation cleavage. Journal of Geology 85, 229-235.

Gray, D.R., 1977b. Differentiation associated with discrete crenulation cleavages. Lithos 10, 89-101.

Gray, D.R., 1979a. Geometry of crenulation folds and their relationship to crenulation cleavage. Journal of Structural Geology 1, 187-205.

Gray, D.R., 1979b. Microstructure of crenulation cleavages: an indicator of cleavage origin. American Journal of Science 279, 97-128.

Gray, D.R., Durney, D.W., 1979a. Investigations on the mechanical significance of crenulation cleavage. Tectonophysics 58, 35-80.

Gray, D.R., Durney, D.W., 1979b. Crenulation cleavage differentiation: implications of the solution-redeposition process. Journal of Structural Geology 1, 73-80.

Grossi-Sad, J.H., Lobato, L.M., Pedrosa-Soares, A.C., Soares-Filho, B.S. (Eds.), 1997. Projeto Espinhaço em CD-ROM Belo Horizonte, Brazil, Companhia Mineradora de Minas Gerais Belo Horizonte, Brazil, Companhia Mineradora de Minas Gerais, vol. 2. 693pp.

Ham, A.P., Bell, T.H., 2004. Recycling of foliations during folding. Journal of Structural Geology 26, 1989-2010.

Lexa, O., Cosgrove, J., Schulmann, K., 2004. Apparent shear-band geometry resulting from oblique fold sections. Journal of Structural Geology 26, 155-161.

Lima, S.A.A., Martins-Neto, M.A., Pedrosa-Soares, A.C., Cordani, U.G., Nutman, A., 2002. A Formação Salinas na área-tipo, NE de Minas Gerais: Uma proposta de revisão da estratigrafia da Faixa Araçuaí com base em evidências sedimentares, metamórficas e idades $\mathrm{U}-\mathrm{Pb}$ SHRIMP. Revista Brasileira de Geociências 32, 491-500.

Machado, N., Schrank, A., Abreu, F.R., Knauer, L.G., Almeida-Abreu, P.A., 1989. Resultados preliminaries da geocronologia U-Pb na Serra do Espinhaço Meridional. Sociedade Brasileira de Geologia, Núcleo Minas Gerais, Boletim 10, 171-174.

Malavieille, J., 1987. Kinematic of compressional and extensional ductile shearing deformation in a metamorphic core complex of the northeastern Basin and Range. Journal of Structural Geology 9, 541554.

Malavieille, J., 1993. Late Orogenic extension in mountain belts: insights from the Basin and Range and the Late Paleozoic Variscan Belt. Tectonics 12, 1115-1130.

Malavieille, J., Taboada, A., 1991. Kinematic model for postorogenic Basin and Range extension. Geology 19, 555-558.

Malavieille, J., Guihot, P., Costa, S., Lardeaux, J.M., Gardien, V., 1990. Collapse of the thickened Variscan crust in the French Massif Central: Mont Pilat extensional shear zone and St. Etienne Late Carboniferous Basin. Tectonophysics 177, 139-149.

Marlow, P.C., Etheridge, M.A., 1977. Development of a layered crenulation cleavage in mica schists of the Kanmantoo Group near Macclesfield, South Australia. Geological Society of America Bulletin $88,873-882$.

Marshak, S., Alkmim, F.F., 1989. Proterozoic contraction/extension tectonics of the southern São Francisco region, Minas Gerais, Brazil. Tectonics 8, 555-571.

Martins-Neto, M.A., Pedrosa-Soares, A.C., Lima, S.A.A., 2001. Tectonosedimentary evolution of sedimentary basins from Late Paleoproterozoic to Late Neoproterozoic in the São Francisco craton and Araçuaí fold belt, eastern Brazil. Sedimentary Geology 141-142, 343-370.

Ménard, G., Molnar, P., 1988. Collapse of a Hercynian Tibetan Plateau into a Late Paleozoic European Basin and Range Province. Nature 334, 235-237.

Noce, C.M., Silva, L.C., Pedrosa-Soares, A.C., Alkmim, F.F., Peres, G.G., 2003. O embasamento da faixa Araçuaí no bloco Guanhães: Dados geocronológicos e evolução: XII Simpósio de Geologia de Minas Gerais, Ouro Preto. Sociedade Brasileira de Geologia, Núcleo Minas Gerais, CD-ROM, 90

Norton, M.G., 1986. Late Caledonide extension in Western Norway: a response to extreme crustal thickening. Tectonics 5, 195-204.

Passchier, C.W., 1991. Geometric constraints on the development of shear bands in rocks. Geologie en Mijnbouw 70, 203-211.

Passchier, C.W., Trouw, R.A.J., 1996. Microtectonics. Springer, Berlin. 289pp.

Pedrosa-Soares, A.C., 1995. Potencial Aurífero do Vale do Araçuaí, Minas Gerais: História da exploração, geologia e controle tectono-metamófico. Dr. Thesis, Intituto de Geociências da Universidade de Brasília, Brasília, 177pp.

Pedrosa-Soares, A.C., Wiedemann-Leonardos, C.M., 2000. Evolution of the Araçuaí Belt and its connection to the Ribeira Belt, Eastern Brazil. 31st International Geological Congress, Rio de Janeiro, 265-285.

Pedrosa-Soares, A.C., Noce, C.M., Vidal, P., Monteiro, R.L.B.P., Leonardos, O.H., 1992. Toward a new tectonic model for the Late Proterozoic Araçuaí (SE Brazil)—West Congolian (SW Africa) belt. Journal of South American Earth Science 6, 33-47.

Pedrosa-Soares, A.C., Vidal, P., Leonardos, O.H., Brito-Neves, B.B., 1998. Neoproterozoic oceanic remnants in Eastern Brazil: further evidence and refutation of an exclusively ensialic evolution for the Araçuaí-West Congo Orogen. Geology 26, 519-522.

Pedrosa-Soares, A.C., Noce, C.M., Wiedemann, C., Pinto, C.P., 2001. The Araçuaí-West Congo Orogen in Brazil: an overview of a confined orogen formed during Gondwanaland Assembly. Precambrian Research $110,307-323$.

Peres, G.G., Alkmim, F.F., Jordt-Evangelista, H., 2004. The southern Araçuaí belt and the Dom Silvério Group: geologic architecture and tectonic significance. Annals of the Brazilian Academy of Sciences 76 (4), 771-790.

Platt, J.P., 1979. Extensional crenulation cleavage. Journal of Structural Geology 1, 95 .

Platt, J.P., 1984. Secondary cleavages in ductile shear zones. Journal of Structural Geology 6, 439-442.

Platt, J.P., Vissers, R.L.M., 1980. Extensional structures in anisotropic rocks. Journal of Structural Geology 2, 397-410.

Platt, J.P., Vissers, R.L.M., 1989. Extensional collapse of thickened continental lithosphere: a working hypothesis for the Alboran Sea and Gibraltar arc. Geology 17, 540-543.

Porada, H., 1989. Pan African rifting and orogenesis in southern to Equatorial Africa, and Eastern Brazil. Precambrian Research 44, 103-136.

Rey, P., Vanderhaeghe, O., Teyssier, C., 2001. Gravitational collapse of the continental crust: definition, regimes and modes. Tectonophysics 342 , 435-449.

Rickard, M.J., 1961. A note on cleavages in crenulated rocks. Geological Magazine 98, 324-332.

Silva, L.C., Armstrong, R., Noce, C.M., Carneiro, M.A., Pimentel, M.M., Pedrosa-Soares, A.C., Leite, C.A., Vieira, V.S., Silva, M.A., Paes, V.J.C., Filho, J.M.C., 2002. Reavaliação da evolução geológica em 
terrenos pré-cambrianos brasileiros com base em novos dados $\mathrm{U}-\mathrm{Pb}$ SHRIMP, Parte II: Orógeno Araçuaí Cinturão Mineiro e Cráton São Francisco Meridional. Revista Brasileira de Geociências 32, 513-528.

Spencer, J.E., 1984. Role of tectonic denudation in warping and uplift of low-angle normal faults. Geology 12, 95-98.

Tack, L., Wingate, M.T.D., Liégeois, J.-P., Fernandez-Alonso, M., Deblond, A., 2001. Early Neoproterozoic magmatism (1000-910 Ma) of the Zadinian and Mayumbian Groups (Bas-Congo): onset of Rodinia rifting at the western edge of the Congo craton. Precambrian Research $110,277-306$

Trompette, R., 1997. Neoproterozoic ( $\sim 600 \mathrm{Ma})$ aggregation of Western Gondwana: a tentative scenario. Precambrian Research 82, 101-112.

Twiss, R.J., Moores, E.M., 1992. Structural Geology. W.H. Freeman \& Company, New York. 532pp.

Uhlein, A., 1991. Transição cráton—faixa dobrada: um exemplo do cráton São Francisco e da Faixa Araçuaí (ciclo Brasiliano) no Estado de Minas Gerais. Dr. thesis, Instituto de Geosciências, Universidade de São Paulo, São Paulo, 295pp.

Uhlein, A., Trompette, R., Egydio da Silva, M., 1986. Estruturação tectônica do Supergrupo Espinhaço no região de Diamantina (M.G.). Revista Brasileira de Geociências 16, 212-216.
Uhlein, A., Trompette, R., Egydio-Silva, M., 1998. Proterozoic rifting and closure, SE border of the São Francisco Craton, Brazil. Journal of South American Earth Sciences 11, 179-189.

Uhlein, A., Trompette, R., Alvarenga, C.J.S., 1999. Neoproterozoic glacial and gravitacional sedimentation on a continental rifted margin: the Jequitaí-Macaúbas sequence (Minas Gerais, Brazil). Journal of South American Earth Sciences 12, 435-451.

Vanderhaeghe, O., Teyssier, C., McDougall, I., Dunlap, W.J., 2003. Cooling and exhumation of the Shuswap metamorphic core complex constrained by ${ }^{40} \mathrm{Ar} /{ }^{39} \mathrm{Ar}$ thermochronology. Geological Society of America Bulletin 115, 200-216.

White, S.H., Burrows, S.E., Carreras, J., Shaw, N.D., Humphreys, F.J., 1980. On mylonites in ductile shear zones. Journal of Structural Geology 2, 175-187.

Whitney, D.L., Teyssier, C., Vanderhaeghe, O., 2004. Gneiss domes and crustal flow. Geological Society of America Special Paper 380, 15-33.

Worley, B., Powell, R., Wilson, C.J.L., 1997. Crenulation cleavage formation: evolving diffusion, deformation and equilibration mechanisms with increasing metamorphic grade. Journal of Structural Geology 19, 1121-1135.

Zheng, Y., Wang, T., Ma, M., Davis, G.A., 2004. Maximum effective moment criterion and the origin of low-angle faults. Journal of Structural Geology 26, 271-285. 